\title{
Unpacking the nexus between policy field, risk management and environmental externalities in adaptation planning: The case of smallholder farmer production systems, western Kenya
}

\author{
Volenzo T. E** and Odiyo, O.O \\ School of Environmental Sciences, University of Venda, P.o. Box Private Bag 0950 Thohoyandou, \\ Republic of South Africa
}

**** Author for all Correspondence volenztom@gmail.com or Tom.Elijah@univen.ac.za +27734561800

\begin{abstract}
The urgency to address the adverse impacts of climate change on livelihoods and ecosystems has seen an increase in global driven initiatives. However, shifting vulnerabilities associated with land use resource based adaptation and maladaptive feedback loops they create have been given low attention. Policy discourses that frame adaptation as a local responsibility and bias towards reducing industrial Greenhouse gas (GHG) emissions at the expense of Agricultural emissions across scale are thought to account for the undesirable situation. This calls for a reflective policy framework and climate policy innovation. We provide counter arguments using Drivers, Pressure, State, Impact, Response (DPSIR) model and telecoupling principles to suggest use of resilience as an integrative lens in visualising the proposal. Using a case study on resource constrained smallholder dairy production systems, western Kenya, we analyse the critical issues in the context of decision making and environmental externalities. The effect of price risks on dairy cattle feeding strategies and ultimately carbon footprints and ecoefficiencies were examined through methane simulation and gross margin analysis (GM). The lowest ecoefficiency was associated with exclusively local coping strategies i.e. Maize Stover (Ms), while the highest ecoefficiency was observed in feeding strategies that utilise external resources and/or legume fodders. We conclude that management of externalities need to capture institutional, economic processes and incentive systems, as well as organizational and policy coherence to shape the interests and behaviour of individual land user. In particular, policy innovation should focus on price and market risks as critical factors that mediate actor decision making at implementation level as they impact GHG emissions which transcend individual decision boundaries.
\end{abstract}

Key words: Climate Action, Climate Policy Innovation (CPI), Effectiveness, Shifting vulnerabilities, Green House Gases (GHGs), Sustainable Development Goals, Telecoupling, Transformation, Resilience, Policy field

\subsection{INTRODUCTION}

Climate change and its mitigation is one of the urgent challenges facing humanity (Burch et al., 2019; Steffen et al., 2018). In context of large scale processes, climate change risks provide a good example of common pool problems whose effects transcend social and spatial boundaries (Burch et al., 2019, Smith and Mayer , 2018). In agriculture spatial externalities, such as Greenhouse gas emissions (Liu et al., 2015), have the potential to amplify the adverse climate change impacts (Parish et.al., 2018). The cross scale challenges engendered in GHG (Greenhouse gases) emissions threaten to undermine the ability of individuals and communities to effectively cope and respond to disaster risks (Burch et al., 2019; Cash et al., 2006), including the attainment of Sustainable Development Goals (SDGs). As externalities transcend spatial territories, jurisdictions and agents, effective governance and accounting systems are necessary (Liu et al., 2018). Accordingly, GHG emissions mitigation initiatives have emerged as critical in the 
analysis of Human-Environment (H-E) systems (IPCC, 2019). Focus on effectiveness thus has emerged as critical to adaptation planning (Nalau et al., 2015; Folke, Hahn, Olsson, \& Norberg, 2005). The paradigm shift is a dominant theme post Paris agreement hereafter referred to as COP 21. The shift is largely informed by need for impactful climate change mitigation pathways (UN, 2015a, UNFCC, 2018; UN, 2019), the need to mitigate humanitarian and economic losses and disruptions associated with increasing frequency and intensity of climate related disasters such as droughts, as well as political uncertainity over intended withdrawal from conference of Parties (COP) by United States of America (UNFCC, 2018).

Land use is one of the critical sectors in decarbonisation efforts (Otto, Donges, Cremades, Bhowmik, \& Hewitt, 2020; IPCC, 2019). This could be realised in smallholder production systems whose impact on global resource use and environmental services, food and externalities and sustainability in general is potentially huge (Niles et al.,2018; Zimmerer et al., 2018). Attention to maladaptive practices that exercabate GHG effect, more so in Agriculture, Forest and land use (AFOLU) is critical as they account for at least 23\% of the global emissions (UN, 2019; IPCC , 2019; FAO, 2016). Importantly, existing analytical lenses and perspectives, such as telecoupling, as well as climate research and policy discourses have tended to underestimate the contribution of small-scale farmers in closing global GHG mitigation gaps (Zimmerer et al., 2018). This increases the need for assessment of full mitigation potential and mainstreaming of agricultural emissions into climate policy (IPCC, 2019; FAO, 2016).

Ideally, adaptation should encompass changes in processes, practices, structures and institutions (Nalau, Preston, \& Maloney, 2015; Adger, Arnell, \& Tompkins, 2005). The adjustment to the adverse impacts and taking advantage of the opportunities presented in climate change is thus influenced both by internal and external drivers (Massey et.al., 2014), with adaptation pathways having untapped potential to reduce global GHG emissions and future climate change risks (Niles et al; 2018; IPCC, 2019). The contribution of local action to GHG mitigation is critical in global sustainable development initiatives and climate action (Jiménez et.al., 2020), especially with emergence of adaptation emissions or footprints in smallholder farmer production systems where maladaptive actions (i.e. those associated with dairy feeding strategies) could increase GHG emissions and exacerbate climate change challenges (Hopkins, 2014).

Novel framing in which policy innovation play a critical role in the design, diffusion and uptake of policies (Massey et.al., 2014), suggest adoption of integrated frameworks to visualise multilevel coupling between social and environmental interactions at local, regional and global levels (Hull \& Liu, 2018; Liu et al., 2013). Key among the broad agenda in policy innovation is system and integrative frameworks that consider decision making (Otto et al., 2020; Weitz et.al., 2017; Gorddard et.al., 2016). Accordingly, several approaches, such as the transformative, environmental justice and business as usual (BAU) models have been advanced in the decarbonation and climate stabilization initiatives (Steffen et al., 2018). A focus on incentives which embodies actor interests are critical in assessing policy integration and effectiveness (Swart et al 2013), more so in the resolution of scope challenges, such as the negative environmental externalities, as well as the free rider and isolation dilemmas, all of which are underpinned by the question around who bears the costs and accrues benefits (Ingram et al., 2007). Since management solutions are critical in climate policy integration (Weitz et al., 2017), focus on farmer management actions becomes an urgent need (Lockwood et.al., 2010).

Intuitively, values are critical in policy problematisation, coherence and effectiveness (Weitz et al., 2017). Decision making and transformative agenda are particularly critical for land use based adaptation planning in developing countries where agriculture is the main economic and livelihood activity (Loboguerrero et al., 2019). Decision making process, such as the choice of dairy cattle feeding strategies is critical in the type and magnitude of environmental impacts, with dairy-agroforestry integration representing a good case study on the interplay of land use, risk and environmental externalities. To this end, we draw from two approaches, Drivers, State, Pressure, Impact, Response (DPSIR) and telecoupling to concretise how integrated risk management can be operationalised to contexts in climate policy 
discourses. We assess and adopt the interplay between price risks and methane emissions in dairy cattle feeding as an opportunity for climate policy innovation (CPI). We illustrate this with a case study from western Kenya where the interlay of price risks, GHG emissions and management decisions captures the convergence on decision making processes. In exploring this relationship, we sought to answer the following questions;

1. Does adaptive capacity influence environmental footprints such as methane emissions?

2. Can individual risk disposition and decision making at micro landscape impact global climate?

We define effectiveness as the extent to which a policy instrument inter alia regulations, standards and voluntary mechanisms aid the pursuit of an environmental objective, such as GHG emission reduction or zero carbon growth initiatives. In Environment management and sustainability discourses, effectiveness is primarily assessed in terms of a minimum number of primary agents .i.e. critical mass, required to reach thresholds that tip the state of an environmental system from undesirable to desirable state i.e. GHG neutral state or net carbon sink. We thus vouch for resilience as a framing and analytical lens in CPI and resolving the dilemma of adaptation-mitigation dualism among climate policy analysts. As the integration of broader development goals and climate-risk management objectives (Barreteau et al., 2020; Thapa, Scott, Wester, \& Varady, 2016) is critical in adaptation and mitigation policies, local contexts could provide opportunity to promote adaptive management, learning, innovation and transformation (Nunan et al., 2012). This article contributes towards the development of a reflective framework for assessing policy blind spots around local-global partnership building, inclusivity of agricultural emissions in global climate agenda, resilience programming and optimization of adaptationmitigation synergies for effective climate action.

\subsection{Role of policy in climate change adaptation}

In decarbonisation of economies critical reflexivity to manage internal processes of change at individual, organisational and technological level is key in addressing the transformative agenda (Otto et al., 2020; UN, 2019; Tvinnereim \& Mehling, 2018; Pelling et al., 2015). The role of policy and institutions in thus very critical (UNEP, 2011). Policy is deliberate effort to influence the behaviour and decision making of various agents via various means interlia, regulatory, communicative, information and economic instruments (Mees et al., 2014; Massey \& Huitema, 2013). It infers the statement of intent backed by governance, such as regulatory tools, as well as requisite financial and human resources to address a given issue (Massey \& Huitema, 2013). It includes use of holistic framing and innovative instruments to generate fundamental change in approaches and steering mechanisms that address a given policy problem (Hall, 1993). In land use, the choice and implementation of policy instruments influence future climate risks and sustainability outcomes (IPCC, 2019). Policy is especially critical in fostering collective action and ultimately effectiveness in many of the sustainability problem areas (Mees et al., 2014; Adger, Arnell, \& Tompkins, 2005).

Norms, rules, policies and laws collectively defined as institutions are critical drivers, constraints or enablers of human economic (in)action (North, 1991). At local level institutions in form of policy instruments, such as subsidies and taxes influence farmer responses (Lewis, Barham, \& Zimmerer, 2008). In relation to climate change adaptation, policy can be defined as decisions and actions that mediate adjustment to and minimise adverse impacts while taking advantage of opportunities presented therein (Dupuis \& Knoepfel, 2013). Policies not only provide a supportive environment but also guide stakeholders in planning and executing adaptation interventions which enables farming communities to adjust to changing climate while taking advantage of any presented opportunity (urwin \& jordan, 2008). Policy is especially critical in in fostering collective action and ultimately effectiveness (Mees et al., 2014; Paavola \& Adger, 2006), .i.e. resolution of functional misfit (Adger, Arnell, \& Tompkins, 2005).

To a great extent, policy field refers to the highest unit of governing in terms of institutions, policy products/inputs i.e. policy, programs, legislation and rules and expertise evidenced through 
knowledgeable persons, coalitions and thinktanks (Massey \& Huitema, 2013). Working in tandem or policy field is critical in the management of a public issue or set of issues a cross steering mechanisms such as the state, nonstate actors and the primary agents or citizens with potential to deal with problems or issues in a particular field in a systematic manner (Massey et al., 2014). The minimum requisite for a policy field are institution order, substantive expertise and substantive authority. Table (1) summarises an ideal description of a policy field. Ideally policy fosters new policy fields in environmental management i.e. innovative instruments, such as voluntary action, emission trading and PES, instruments and institutions that can be used to enhance ownership and participation or legitimacy (Jordan et al., 2013). These include equity considerations, which in policy and practice, can be balanced by a mix of both market i.e. use of carbon taxes and non-market mechanisms to address emissions leakages (IPCC, 2019). In our framing, effective policy requires an understanding on the interplay between primary actors' production, market and price risk constraints and potential outcomes at local and extra local levels.

The matching or confluence of key Human-Environment (H-E) interaction attributes, and the institutions designed to steer them, define fit (Young, 2006; Ostrom, 1990). Fit is reflected in the extent to which policy captures and addresses scope issues, such as externalities, as well as temporal dimensions i.e. preferences and motivations of the agents (Young, 2006; Rijke et al., 2012). The interplay of fit and scale are thus key governance challenges in the management of externalities. This is particularly critical in in the reduction of GHG mitigation gaps under the climate action goal of the SDGs (UNEP, 2019). Process dimensions i.e. the establishment of standard operating procedures, such as Environmental Impact Assessment(E.I.A), Strategic Environmental Assessment (SEA), Regulatory Impact Assessment (Weitz et al., 2017; Vammen et al., 2012), are some of the critical elements in attainment of fit. Given that policy design coherence and integration minimises trade-offs and leverages on synergies, effective CPI in land use is judged on the extent to which mitigation and adaptation objectives are mainstreamed into sectoral policies (Di Gregorio et al., 2017), as well as the extent to which climate change and overall development goals are integrated. The enactment of National Adaptation plans (Napas) is one such indicator in CPI. However, Napas in themselves may fail to elaborate the implementation, monitoring and evaluation mechanisms for assessing effectiveness even if they increase the visibility of climate change challenges into national policy discourses (Biesbroek et al., 2010).

Table 1: Summary of policy field in climate change adaptation

\begin{tabular}{|l|l|l|}
\hline $\begin{array}{l}\text { Policy } \\
\text { component }\end{array}$ & $\begin{array}{l}\text { Description and } \\
\text { operationalisation }\end{array}$ & Evidence \\
\hline $\begin{array}{l}\text { Institutional } \\
\text { Order(IO) }\end{array}$ & $\begin{array}{l}\text { Refer to authorised } \\
\text { legitimate government } \\
\text { institutions with power } \\
\text { and/ or expertise to steer } \\
\text { or oversight an issue .i.e. } \\
\text { the institutions that order } \\
\text { and structure policy } \\
\text { responses (Massey et al., } \\
\text { 2014). }\end{array}$ & $\begin{array}{l}\text { Types and number government institutions that } \\
\text { produce policy products/outputs and devoted to } \\
\text { adaptation(Massey et al., 2014). This includes the } \\
\text { presence of a lead agency that coordinates and oversees } \\
\text { the whole adaptation process and acting as secretariat } \\
\text { for disaster risk assessment evidenced through } \\
\text { - Multi-stakeholder coordinating body }\end{array}$ \\
\hline $\begin{array}{l}\text { Substantive } \\
\text { Authority(SA) }\end{array}$ & $\begin{array}{l}\text { What gives meaning and } \\
\text { legitimacy to the policy } \\
\text { actors, moreso the } \\
\text { coordinating agency }\end{array}$ & $\begin{array}{l}\text { - It is reflected in policy products and outputs } \\
\text { including programs, legislation and rules } \\
\text { (Massey et al., 2014) }\end{array}$ \\
\hline $\begin{array}{l}\text { Substantive } \\
\text { Expertise(SE) }\end{array}$ & $\begin{array}{l}\text { Evidence of expert } \\
\text { knowledge among state }\end{array}$ & $\begin{array}{l}\text { presence/ and or absence of working/steering groups, } \\
\text { task forces, policy networks, citizen interest groups, }\end{array}$ \\
\hline
\end{tabular}


and non-state actors in adaptation planning (Massey \& Huitema, 2013) policy papers and proposals, studies, reports, issue papers-

Policy coherence signals the optimisation of synergies and positive externalities (co-benefits). In climate policy, it is assessed in terms of how sectoral and broader development objectives are integrated through a central authority (Di Gregorio et al., 2017). Policy coherence is critical in mobilising private actors towards resolution of collective problem (Dupuis \& Knoepfel, 2013), and mediates effectiveness in localglobal policy initiatives (Otto et al., 2020), where critical mass is required to mediate adoption trajectories inter alia behavioural, social norms and structural reorganisation (Milkoreit et al., 2018), as well as provide reinforcing feedback mechanisms (Otto et al., 2020). Critical mass is especially relevant in cross scale governance of GHG spillover systems (Liu et al., 2018). Accordingly, policy coherence and integration (Lemos et al., 2013), is critical in managing maladaptive outcomes. Addressing adaptationmitigation dualism in climate policy and research could redefine how effectiveness is assessed.

\subsection{Risk, Micro level decision making and environmental impacts}

The availability of resources and ability to utilise them greatly influences the adaptive capacity of an individual and communities (Nelson et al., 2007). Theoretically generic capacity is a precondition for specific capacity and risk management (Eakin et al., 2014), with their interplay being critical in policy coherence. In adaptation policy, adaptive capacity and coping mechanisms largely focuses on local resource capacity (Kuruppu \& Willie, 2015). Since coping mechanisms represent specific capacity, it is critical in risk innovation and resilience building (Kuruppu \& Willie, 2015; Eakin et al., 2014), moreso because they are correlated to maladaptive outcomes (Suckall et al., 2014). Maladaptation creates shifting vulnerabilities whose social costs impact beyond the primary agents' jurisdiction (Barreteau et al., 2020; Adger, Eakin, \& Winkels, 2009).

Given that policy innovation is assessed by the extent to which it is responsive to felt needs (Massey \& Huitema, 2013), there is need for policy coherence metrics to consider decision making and management of externalities (Weitz et al., 2017). The use of risk-based decision-making tools to address time related preferences of an individual (Nelson, Adger, \& Brown, 2007), as well as the capture of institutional, economic processes and incentive systems that shape the behaviour of land users and management of externalities (Xu et al., 2015; Ostrom, 2007) is critical. We demonstrate how dairy cattle feeding adaptation strategies in climate risk management influences methane emissions and ultimately impact climate at scale. We restrict ourselves to dairy cattle (domesticated ruminants), as it is a major driver of GHG emissions and climate spillover system (Meng, Peters, \& Wang, 2015; Geber et al., 2013). The micro, meso and macro interplay provides a good case study on cross scale governance challenges, the need for global partnership and inclusivity in on climate action.

Though some studies (Tessema, Joerin, \& Patt, 2019) account for the role of risk in uptake of technologies in climate change adaptation, gaps on the role of risk on environmental externalities abound. In agriculture, the interplay of risk and environmental externalities is invariably framed in terms of income and consumption smoothening strategies. In dairy production, the tendency among risk averse farmers on average is to raise breeds that are highly adaptable to the local environment (Williams et al., 2000). This is a consumption smoothing strategy, a common practice among the poor/ resource constrained farmers (You, 2014). At national level, macro-economic policy, input-output price ratio, access to credit, institutions regarding land tenure, and management, approaches to research and extension policy and markets and infrastructure influences farmers risk management strategy (Williams, Hiernaux, \& Fernandez-Rivera, 2000). For instance (Wekesa, Ayuya, \& Lagat, 2018; Shimon, Ogutu, \& 
Mburu, 2016), find profit to be a major motivating factor in adoption of voluntary measures and technologies that internalise environmental externalities.

Pressures or drivers to environmental degradation are critical in enhancing better understanding and managing effects across multiple systems and scales (Suckall et al., 2014). Ruminant livestock, such as dairy cattle generates approximately $14.5 \%$ of the total global GHG emissions (Steinfeld, 2006), which is $44 \%$ of the anthropogenic GHG emissions (Geber et al., 2013). Methane as one of the GHG spillover system impact the world through climate change impacts (Parish et al., 2018; Liu et al., 2018). Livestockagroforestry integration as a management practice thus represents how the interplay between human decision and environmental externalities can be envisioned. Agroforestry encompasses integrated approaches (trees and legumes- livestock integration), production system with high potential in climate change adaptation and mitigation, ecosystem services enhancement and productivity improvement (Murgueitio, Calle, Uribe, Calle, \& Solorio, 2011).

Under COP 21(UN, 2015a), specifically part (3a), pursuit of synergies between adaptation and mitigation is advocated (UNFCC, 2018). The need for policy innovation is thus implicit and provides an opportunity for Cop 21 to be a turning point for individual and collective action innovation in climate change action and resilience building (UN, 2019). In context of GHG mitigation and adaptation, there should be a focus on the interplay between local interests, institutional framework and fundamental drivers of the problem in the design of programmes, projects and policies (Barreteau et al., 2020; Burch et al., 2019). Combining the effect of adaptation and mitigation pathways on GHG mitigation have the potential to improve the generation of ecosystem services and improve attract funding through multilateral agreements and market based instruments, such Payment for Ecosystem Services (UN, 2019; Elias et al., 2014; Lachapelle et al., 2013).

(Intended) Nationally Determined Contributions (I)NDCs initiative represent the main national policy frameworks, under the United Nations Framework Convention on Climate Change (UNFCCC), by which Parties to the Paris Agreement communicate their climate commitments to the international community by outlining their progress and resource gaps (UNFCC, 2018). We posit that (I)NDCS could be a focal point for policy innovation i.e. the inclusion of agriculture emissions in global climate change mitigation agreements and risk transformation. (I)NDCS (Fig 1) as conceptualised in our article has the potential to promote stakeholder confluence and address the scale and cognitive challenges, such as the interconnected externalities in land use. This is more critical where individual or local level contribution, (more so from the dominant agricultural sector in developing countries) has been accorded low attention in most climate action policies (Calvin\&Bond-lamberty, 2018). 


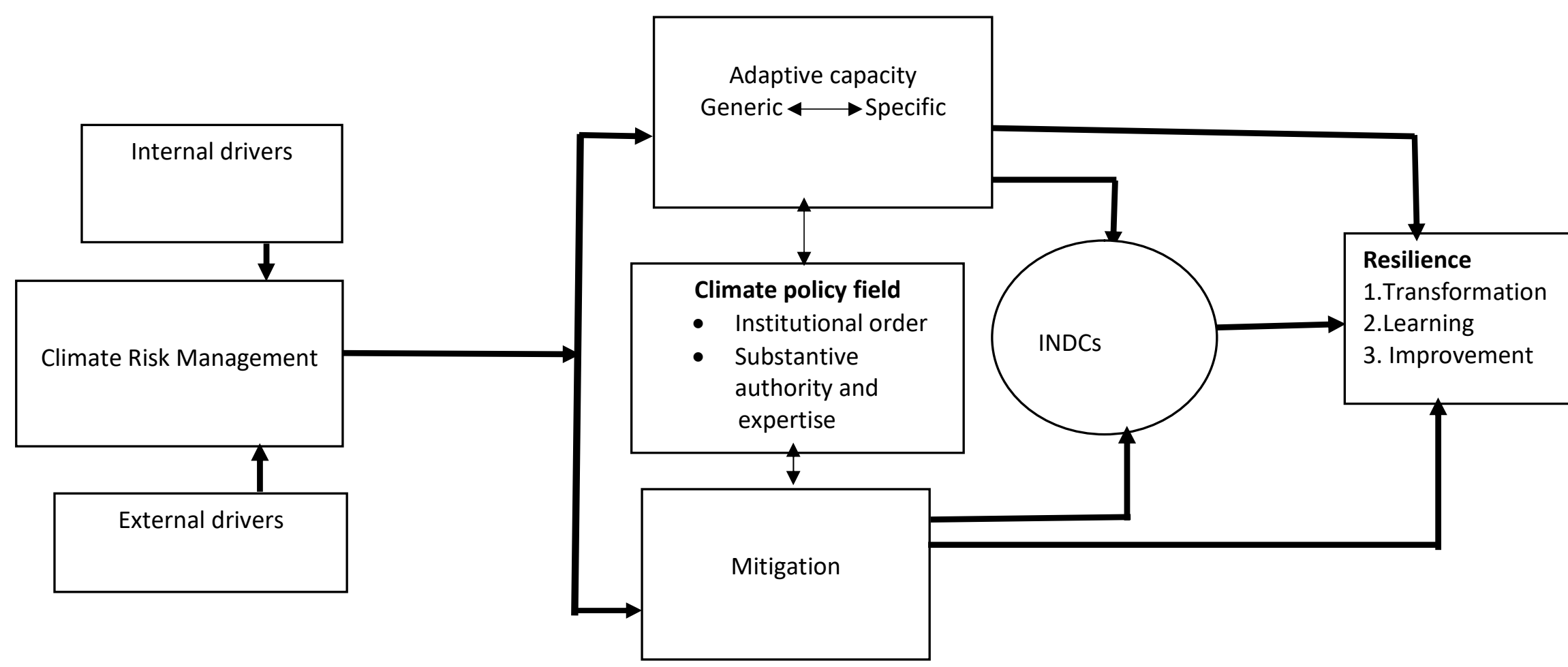

Fig 1: Adaptation-Mitigation interplay through resilience lenses and UNFCC intended National Determined Contributions( Authors' synthesis of literature). Resilience as the ultimate goal in climate change policy and carbon neutral growth can be realized through both adaptation and mitigation ( on the basis of the major economic sector of a country ) hence use of complimentary as the logical basis for prioritization of either pathway. (I)NDCs thus provides a window of opportunity for innovation in environmental governance in general and inclusive closing of GHG mitigation gaps from agricultural activities in particular. 


\subsection{The Kenyan Dairy production in Context}

Generally, smallholders are constrained due to a number of factors, interlia institutional failures, market and price risks, all (in)directly linked to weather fluctuations (Becx et.al., 2012). In Kenya, 1.8 Million small-scale farmers account for $73 \%$ of all marketed milk (KNBS, 2017). Annual production milk production stands at 5.28 Billion litres from 4.5 Million heads of cattle of which 0.6 Billion litres is marketed formally (KDB, 2020). The dairy production system, however is generally inefficient and characterised by high production, market and price risks (FAO, 2019). Western, Kenya is disproportionately representative of low institutional support in the smallholder dairy sector which amplifies the risks for farmers. None of the 23 processors and only a few of the 47 cooling plants are found in Kakamega and Bungoma counties (KDB, 2020). we Though promotion of fodder production and preservation across various agroecological zones has been promoted to address production risks, dismal uptake has been observed among smallholder farmers (Rademaker et al. 2016). Climate hazards across different sectors cause economic losses estimated at 3\% ( G.o.K, 2015) of the country's Gross Domestic Product (GDP), more so in the highly climate sensitive agriculture sector.

Under the two tier governance system, the development of agricultural policy is the responsibility of the central Government, while the implementation is the responsibility of the county governments (Makoni et al. 2014). Such governance, however tend to undermine organizational and policy coherence as allocated resources by central government to devolved units do not seem to match the devolved functions. In particular, the price policy is not in the purview of devolved units which renders such units powerless in price policy and price risk policy responses. In most cases, policy responses have been adhoc and more so to pacify farmers rather than to address the underlying constraints that undermine resilience building to market and production risks. For example, though vertical integration approaches which have potential to address credit and input constraints, as well as processing capacity among small scale farmers (Williams et al., 2000) are policy relevant and sustainable, the focus of most county governments has been on hardware solutions (Bebe et al., 2016) i.e. construction of milk sheds, which to a large extent fail to sustainably address the price risk constraints.

In many systems where fodder is in short supply, variation in quantity is much more important than variation in quality for determining nutrient supply to the animal (Thorne et al., 2002). The increasing supply of milk from smallholder farmers across agro-ecosystems in Kenya is however accounted for by increased number of producers rather than productivity in such systems. This production strategy results in high production costs and presents ecological threats to land, soil, water, and biodiversity (Bebe et al., 2016), as well as increased methane emission risks (Volenzo et al 2019; FA0, 2019). This is especially true for the study area from a view point of weather variability, underlying and on-going vulnerabilities, such as low fodder acreages and land subdivision, all which amplifies production risks.

\subsection{METHODOLOGY}

\subsection{Theoretical background}

Most of the natural resource management technologies have both larger spatial scales and longer time horizon impacts or externalities and affect economic units or households that are not party to management decision (Knox, Meinzen-dick, \& Hazell, 1998). In the context of SDG on climate action for GHG mitigation and adaptation, increased need to frame of food systems around the principles of sustainability increases due to the layered nature of agents within and among countries which necessitates multilevel efforts or global strategy in search of effectiveness (Burch et al., 2019; Rey et al., 2017). It is more so in passive spillover systems where agents do not directly influence the process in GHGs emissions (Liu et al., 2018). Framing and causal relationships is thus critical in visualising externalities and sustainability in land use (Ness et al., 2010). For example, short term decisions on risk management influence allocation of assets (Siegel \& Alwang, 2005), with far reaching impact on sustainability and poverty dynamics. Evaluation of market infrastructure and incentives as critical determinants of intensification in adaptation (Paavola, 2008) are critical in our 
case study.. This is on account that (in)formal institutions provide signals on production and price risks or the constraining factors that affect the flow of spillovers between the sending, receiving and spillover system (Parish et al., 2018). Our classification of spillovers as spatial externalities and leakages from (in)direct land use changes associated with climate change adaptation follows spillover system classification (Friis \& Nielsen, 2017). Our methodology, specifically the assessment of interplay between externalities and adaptation decision making processes is based on dairy feeding strategies as to provide a baseline in visioning, scaling up and translation of risk theory into effective climate action.

To put our method to perspective, we critically review performance (strength and weaknesses) of telecoupling and the Drivers-Pressures-State-Impacts-Responses (DPSIR) models in an attempt to integrate the interlay of risk and governance on performance of global and local initiatives on adaptation and climate change mitigation. The strength and weakness of DPSIR and meta (tele)coupling analytical models are summarised in Table (2). As a decision making tool, telecoupling can elicit feedbacks between systems and account for the changes across time (Tara, Killion, \& Carter, 2018). Tele(Meta)coupling as an analytical lens can be explored to examine the often overlooked agent decision making processes ( Liu 2017). As an analytical tool for mainstreaming of sustainability concerns in research and policy (Hull \& Liu, 2018; Parish et al., 2018 ; Liu et al., 2013), it can be explorated to land use changes (Eakin et al., 2014). It can thus be used in examining how legislation, control policies and incentives affect flows, such as GHG emissions and for monitoring, implementation and improvement of environmental governance and policy (Liu, 2017).

The DPSIR framework provides and communicates knowledge on the state and causal factors regarding environmental issue (Ehara et al., 2018; Svarstad et al., 2008). It is applied to identify and describe processes and interactions in H-E, a form of ecosystem approach (Shu-dong, Mueller, Bur, Xing-jin, \& Ying, 2013). The bias of DPSIR model towards a single sector, ecological or biophysical factors or socio-cultural dimensions, however limits its utility (Lewison et al., 2016), especially where broad policy measures that address drivers pressures and state as well as behavioural dimensions are required (Ness et al., 2010). Additionally, DPSIR model pays less attention to maladaptive coping strategies (Suckall et al., 2014; Carr et al., 2007). Given that local resources and initiatives are critical in resilience building ((Kuruppu \& Willie, 2015; Wisner et al., 2004), DPSIR is an ineffective risk transformation tool. However, it can facilitate strategic visioning, setup of administrative mechanisms and values, ex ante assessments, inform design of policy instruments, administration of economic, legislative and voluntary mechanisms, as well as guide monitoring and evaluation schemes that assess effectiveness of environmental projects and programs (Swart et al., 2013). We thus combine the two models with a view of addressing specific limitations of the two and informing CPI. 
Table 2: strength and weakness in policy assessment model

\begin{tabular}{|c|c|c|}
\hline & \multicolumn{2}{|l|}{ Model } \\
\hline & DPSIR & Telecoupling \\
\hline Strength & $\begin{array}{l}\text { Enables integrative, multidimensionnel assessments (Ness et al., } \\
\text { 2010) } \\
\text { - Identifies and visualises cause-effect relationships (Smalling and } \\
\text { Dixon, 2006;Ness, Anderberg, \& Olsson, 2010) } \\
\text { - Communication tool among decision and policy makers (Svarstad } \\
\text { et al., 2008; Ehara et al., 2018;Tscherning, Helming, Krippner, Sieber, } \\
\quad \text { \& Gomez, 2012) } \\
\text { - Participatory planning(Kontogianni et al., 2005) } \\
\text { - Considers cross-sectoral and environmental issues (Niemeijer \& de } \\
\text { Groot, 2008; Ojeda-Martınez et al., 2009) }\end{array}$ & $\begin{array}{l}\text { - Robust approach that facilitates snowballing hence use of grounded } \\
\text { theory (Hull \& Liu, 2018;Liu, 2017; Friis \& Nielsen, 2017) } \\
\text { - Accounts for emission footprints including factors that increase the } \\
\text { likelihood of spillovers (Xiong et al., 2018) and how agents } \\
\text { proactively predict potential negative spillovers (Hull \& Liu, } \\
\text { 2018).The application of metacoupling gives flexibility to disregard } \\
\text { distance magnitude in terms of processes(Hull \& Liu, 2018; Liu, } \\
\text { 2017) } \\
\text { - Ability to assess governance arrangements, social networks, values } \\
\text { and knowledge( Eakin, 2017) }\end{array}$ \\
\hline Weakness & $\begin{array}{l}\text { - Less consideration for maladaptive coping strategies particularly } \\
\text { the informal responses to climate change at local levels yet they } \\
\text { cumulatively influence pressures or drivers, acritical element in } \\
\text { assessment of sustainable development at larger scales such as the } \\
\text { national level (Suckall et al., 2014;Carr et al., 2007), } \\
\text { promotes selective identification of issues which undermines the } \\
\text { linking policy options to land use, land use change, environmental } \\
\text { and social economic impacts (Svarstad et al., 2008). }\end{array}$ & $\begin{array}{l}\text { - Little data or analysis on spillover effects(Liu et al., 2018;Parish et al., } \\
\text { 2018), } \\
\text { - Inadequate to support evidence based policy decisions and analysis } \\
\text { that require data from primary agents (Parish et al., 2018; Xiong et } \\
\text { al., 2018; Olesen, Kittler, \& Price, 2015). } \\
\text { - Robust to allow use of qualitative and ethnographic methods to } \\
\text { capture diffuse flows and their causal interlinkages (Friis \& Nielsen, } \\
\text { 2017) }\end{array}$ \\
\hline
\end{tabular}




\subsection{Field data and literature review}

We employed mixed methods approach consisting of agent survey and methane emission simulation from various dairy cattle feeding strategies. The article findings are supplemented through document analysis and Key Informant (KI) interviews among regulatory, advisory and implementation agencies in Kakamega and Bungoma counties, Western Kenya. To assess production risks, interview among randomly selected farmers was undertaken focussing on the available dairy feeding options and institutional factors influencing their choice. Extensive literature on climate policy was undertaken from Grey literature i.e. books, as well as peer reviewed publications. KI interviews were conducted among formal institutions in land use and climate change action, milk marketing, environmental management, national adaptation strategies and plans. Focus Group Discussion (FDGs) was also undertaken to elicit information on factors influencing choice of dairy feeding strategies. We used smallholder production systems and particularly ruminant production systems and the lens of risk to highlight the increasing attention to shifting vulnerabilities.

\subsection{Empirical models}

\subsubsection{Gross Margin Analysis}

Gross margins of various adaptation measures in terms of dairy cattle feeding strategies were evaluated and compared. Costs for inputs and total revenues obtained from field data were utilized in the comparison. The mathematical model (Equation (1) was applied.

$\mathrm{GM}=\mathrm{P} . \mathrm{Q}-\mathrm{VC}=\mathrm{P} . \mathrm{Q}-\mathrm{V}_{1} \mathrm{X}_{1}-\mathrm{V}_{2} \mathrm{X}_{2}-\ldots \mathrm{V}_{\mathrm{n}} \mathrm{X}_{\mathrm{n}}$

Where $\quad \mathrm{GM}=$ Gross margin

$\mathrm{P}=$ Price of the produce $=$ Quantity of the produce sold

$\mathrm{VC}=$ Total Variable cost of production.

$\mathrm{X}_{\mathrm{i}}=$ Level of $\mathrm{i}^{\text {th }}$ input used; $\mathrm{V}_{\mathrm{i}}=$ Variable cost of $\mathrm{i}^{\text {th }}$ input used

\subsubsection{Methane emissions simulation}

The simulation model adopted follows methanogenesis model as described by (Mills et al., 2003) in equation 2. Modelling saves time and resources and allows for integration of results from many experiments already performed to quantify and represent large and complex systems in a mathematical form which allows for prediction of methane production from cattle without performing extensive and costly experiments (Hirooka, 2010; Ellis et.al., 2007). Simulation of methane emission from different feeding strategies and Ms was carried out and comparisons were made against conventional strategies, namely Napier (Pennisetum species ) and Boma rhodes (Chloris gayana). Simulated quantitative models give a range of scenarios that can be traced in both directions in an iterative way to develop scenarios and project impacts in H-E systems (Turner et.al., 2010; Downing and Patwardhan, 2002). The worst case scenario model can be used in disaster planning (Downing and Patwardhan, 2002). This study used nonlinear monomolecular models due to their adaptability across diet types and intake levels. Non-linear monomolecular models do not require detailed dietary information to be used in simulating methanogenesis in cattle (Mills et al., 2003). Furthermore, non-linear models account better for observations at the extreme methane output feed intake ratios. Comparisons were based on farmer practices, as well as exploratory and practical feeding regimes and rations on all possible ranges. Where information is lacking, estimation of certain inputs can be made according to data published elsewhere in literature (Mills et.al., 2001). Feed value data in the simulation was thus obtained from literature data by Thorne et al., 2002; Debala et.al.,2011; Dereje et.al.,2010; Gebrehawariat et.al, 2010; Muia et.al.,1999; Mills et.al., 2001;2003; Dzowela, 1985; Ashiona et al., 2006; Muinga et al., 1995; 1993 and Smith et al., 1989.

Methane $(\mathrm{Mj} /$ day) $=1.06$ (S.E 2.41) + 10.27(S.E 3.59) dietary forage proportion+ 0.87(S.E 0.074)

DMI.

Where: 


$$
\begin{aligned}
& \text { DMI = Dry matter intake } \\
& \mathrm{SE}=\text { standard error }
\end{aligned}
$$

\subsubsection{Estimation of ecoefficiency}

GHG emissions management policy for the agriculture sector has shifted from absolute emissions to production efficiency with the objective of minimising emission per unit output (UNFCCC, 1998). The global policy is reflected through eco-certification initiatives which guide the global market and provides signals for farmer decision and responsiveness (Zimmerer et al., 2018). Eco-efficiency (equation 3) was thus used as an integrated indicator for assessing the economic and environmental feasibilities (Masuda, 2016). Individual global warming potential for a period of 100 years for each gas was 1 to $\mathrm{CO}_{2}$ and 21 to $\mathrm{CH}_{4}$ (IPCC, 1997). All the emissions were estimated using Intergovernmental Panel on climate change (IPCC) default emission factors in livestock management (IPCC, 2006). To assess the environmental impacts the figures were fed into an equation for calculation of eco-efficiency. Scenarios were thus built to elicit methane emissions levels from various dairy feeding strategies with supplementation levels as proxy for price risks.

Eco-efficiency $=$ Net farm income/ global warming potential

(Non)supplementation levels is an exemplar of interplay between market price risks, institutions, management options and risk attitude. The break-even price for dairy farmers during our survey was Kes 25 (100 Kes = 1 \$) which is the minimum price at which a rational agent will commit to the dairy enterprise. This price level provides the baseline information for evaluation of market risk on ecoefficiency. The mean price for the lower band at Kes (20 and 15) and the upper band at Kes (30 and 45) provide such scenarios. In fitting the data, the 18 litre production level per cow was adjudged as carbon neutral point. 18 litres was thus taken as the reference point for assessing effect of price risks on $\mathrm{CH}_{4}$ emissions and representative of environmental externalities. Three level of dairy productivity viz; the lower production point as 0-9 litres; medium level of 9-18 litres and the upper point of 18-27 litres and 27-36 litres. In Kenya the upper point production levels represents dairy productivity levels is the policy objective in the agricultural sector transformation.

\subsection{Results}

A coherent and effective response to the local, national and global challenges and opportunities on climate change is critical in climate policy. In East Africa, food security, economic, social and environmental objectives are intertwined to guide member countries in framing policy objectives for decoupling GHG emissions from agricultural development (FAO, 2017). Accordingly, Kenya has a number of strategies, governance frameworks, laws and guidelines on climate action such as, the Climate Change Response Strategy (G.o.K, 2010); Climate Smart Strategy (G.o.K, 2017); Agricultural Sector Transformation Strategy (G.o.K, 2019) and Green Economy Strategy under the vision 2030 (G.o.K, 2007). The Green Economy Strategy and Implementation Plan (GESIP), underpins Kenya's commitment to undertake a transition to a green economy (G.o.K, 2007). The NDCs submitted by Kenya largely focus on policies for sustainable agriculture development and climate change action (G.o.K, 2015). The low carbon pathways towards food and nutrition security productivity and resilience in the agricultural sector is reiterated in the national adaptation plan (G.o.K, 2018). The climate resilient, low carbon sustainable agriculture, adaptation to climate, and mitigation (G.o.K, 2017) are consistent with external coherence and integration principles in climate policy discourses.

Policy field is evident in terms of several institutions, policy products/inputs i.e. policy, programs, legislation and rules and expertise evidenced through knowledgeable persons, coalitions and thinktanks that work in tandem (Massey et al., 2014; Massey \& Huitema, 2013). In Kenya policy field in Climate change action is uncoordinated. Though the formulation and setting of sectoral climate change 
units at county level and ministerial and climate change plans under the proposed climate financing program (Republic of Kenya, 2016) suggest semblance of vertical climate policy integration, they do not work to address the Adaptation-mitigation divide and capture synergies a cross steering mechanisms. They are also characterised with inadequate understanding on the interplay of risk on land-use and the potential outcomes at local and extra local levels (Volenzo \& Odiyo, 2020).

The need for vertical and horizontal integration is critical in scale matching .i.e. GHG mitigation with the scale of solution or individual emission contributions to mitigation and local responses (Biesbroek et al., 2010). Policy coherence signals the optimisation of synergies and co-benefits hence reduction of negative interactions with the resulting complementarily between adaptation and mitigation (Di Gregorio et al., 2017), enhancing climate policy integration. Though innovative instruments i.e. Payment for Ecosystem Services (PES) have the potential to reduce GHG emission (Shimon et al., 2016), most of such projects and programs on climate change adaptation and mitigation are donor driven with tendency for duplication (Chesterman \& Neely, 2015). Duplication tend to undermine coherence and effectiveness (Weitz et al., 2017).

Furthermore there seems to be lack of a comprehensive cross-sectoral strategy, as well as overarching goals in the management of environmental externalities in programming. The low horizontal integration is inspite of the presence of National Environmental Management Authority (NEMA) as a central authority in environmental management. Under the climate change Act, policy, coordination and oversight is placed under a directorate in the ministry of environment. However, enforcemt is under NEMA. In previous studies cognitive failure and low capacity on enforcement by NEMA are among key cross scale challenges underlining effectiveness (Volenzo \& Odiyo, 2020). Additionally, most of the national climate change action adaptation plans focuses on coping mechanisms with low attention to procedural mechanisms ( i.e. EIA and SEAs) that may address environmental externalities in adaptation planning.

A review of documents reveal that most of the existing policies, strategies and legislations do not provide for coordination of climate smart Agriculture (CSA) related issues. Further, the various CSA instruments provide limited innovative interventions on adaptation and mitigation. Though several donor funded projects are in place, they do not capture synergy between various sectors .i.e. agroforestry and livestock. This is apparently due to inadequate mechanisms for linkages and coordination between CSA agencies and stakeholders which results in overlaps and inefficiency in implementation of programs (G.o.K, 2017). The fragmentation is especially critical in process of environmental safeguards which requires effective coordination between line Ministry and environmental agency on the coordination of compliance and enforcement of environmental laws.

Kenya's National Adaptation Action Plan (NAPAs), 2015-203 aims to consolidate the country's vision on adaptation. This is evidenced by macro- level adaptation actions that seek to enhance long term resilience and adaptive capacity which have linkages to various economic sectors, as well as the identification of county-level vulnerabilities. However, the existing Napas do not elaborate concrete proposals or processes for implementation and measuring effectiveness. Secondly, the domiciling of Agriculture policy formulation with central government while implementation lies with county governments tend to undermine integration and coherence. This is compounded by lack of expertise at local level in planning and implementation for specific risk assessment and risk management actions inspite of such expertise being available at higher level (G.o.K, 2017). Though there is semblance of highranking institutional mandate and corresponding enforcement mechanisms in climate change action, climate change directorate as the agency with governmental mandate to enforce a top-down form of government-led policy integration, there is risk of conflict in the various agencies. This is aptly captured in inherent conflicts in the mandate of climate directorate and Nema.

Shifting adaptation to local level without corresponding additional support and resources reduce effectiveness in adaptation planning (Nalau et al., 2015). Though Agriculture is the mandate of 
devolved governments, the price policies are not in their purview but the central government. This is compounded by oligopolistic structure in the milk value chain where only 5 of the 23 milk processors ( KDB, 2020) control $80 \%$ of market value and value chain. For example, in 2019, the ministry of Agriculture only intervened after presidential directive to stem widespread discontent among small scale farmers receiving extremely low output prices. In most cases such directives are however shortlived as the cycle of droughts always triggers downward revision of milk prices. Upward revision of prices however seldomly materialises during dry weather with farmers resorting to coping mechanisms, such as Ms without supplementation to manage the market and price risks.

Climate change is a key driver in production and price risks faced by resource constrained farmers in Kenya. The correlation of dairy feeding strategies and methane emissions is thus a window of opportunity in interrogating the framing of adaptation as a local responsibility. Focus on risk aspect in programming is critical as incentives mediate behavioural responses in adaptation action and capturing the full contribution of local action .i.e. agricultural production in mitigation and/or neutralising GHG impacts. Some of the opportunities to incentivise farmers and address market and price risks lie in vertical integration in the milk value chain. Vertically coordinated cooperatives as source of credit, new technologies and stable output market could minimize financial risks faced by the farmer and deepen intensification (Williams et.al., 2000). However, this has been accorded low attention by the county and central governments alike in the process entrenching price and market risks in the dairy industry, more so in areas that are less linked to urban markets.

\subsection{Dairy feeding adaptation strategies and price risks}

FGD, key informant, farmer interviews and observation checklists revealed that Ms and deferred harvesting of napier grass is the most preferred dairy cattle feeding risk management strategy. Deferred harvesting of napier grass as a risk management strategy to weather variability risks was practiced by about $70 \%$ of the respondents who grew the fodder ( Table 1). Less than $15 \%$ and $3 \%$ of the farmers used hay and silage respectively. Cross tabulation of the frequencies reveals that feed conservation is influenced by breed type, agro-ecological zonation and income level from farm and non-farm sources. Silage making an adaptation opportunity, especially during peak and above normal rainfall periods, is poorly adopted. About $85 \%$ of the sampled households attributed this to lack of technical knowhow and information. As a result, surplus fodder available during above normal /peak rainfall periods is wasted. Use of hay legumes was practiced by less than $1 \%$ of the farmers' citing limited land sizes and lack of technical information.

Breeds of low production merit and low management standards were evident in $65 \%$ of households in the main maize zone and $75 \%$ in the main sugarcane zones. This could be a risk management strategy and which contributes to low adoption of feed conservation strategies by farmers. The results from methane simulation suggest that deferred harvesting of Napier is an in-efficient adaptation strategy as it increases methane emission risks by up to $30 \%$ ( Table 6). Though sustainable Ms based rations could be built on existing programmes such as push- pull in striga/stem borer control, fodder legumes and agro-forestry systems, less than $5 \%$ of the sampled farmers used legume fodder as supplements, whereas at least $85 \%$ of the famers used Ms without any supplementation. This is reflected in productivity losses of up to $70 \%$ of the milk production potential during droughts. 
Table 1: Nutritional interventions practiced by farmers
$\%$ Awareness
$\%$ Adopted
OAW $(\%)$
OA $(\%)$

\begin{tabular}{lllllll}
\hline Nutritional & Maize & Sugarcane & Maize & Sugarcane & \\
intervention & zone & zone & zone & zone & \\
Molasses & 25 & 21 & 15 & 12 & 23 & 13.5 \\
Minerals & 48 & 45 & 27.5 & 16.3 & 46.5 & 16.3 \\
Legume fodder & 5 & 7 & 1 & 1 & 6 & 1 \\
Potato vines & 25 & 42 & 13.5 & 33.5 & 33.5 & 24.4 \\
Grain residues & 40 & 23 & 25 & 3 & 31.5 & 14 \\
Silage & 30 & 28 & 3 & 2 & 29 & 2.5 \\
Hay & 76 & 42 & 13 & 9 & 59 & 85 \\
Ms & 95 & 90 & 87 & 83 & 92.5 & 70 \\
Napier (Deferred) & 85 & 75 & 75 & 65 & 80 & 85 \\
\hline
\end{tabular}

Source: Authors field data analysis. OAW; Overall awareness, OA; Overall adopted

The constraints in dairy feeding strategies are summarised in Table (2). About $95 \%$ of the farmers attributed deferred harvesting to lack of knowledge and skills on alternative feed conservation technologies, as well as and lack of capital. The finding suggests that farmers' feed risk management strategies, information/ knowledge gaps and risk attitude can actually exercabate existing disaster risks, such as GHGs emissions and associated global warming outcomes. Silage making was practiced by less than $3 \%$ of the respondents in the study area. As an adaptation strategy, ensiling of fodder resources could ensure optimization of the available rainfall, attain better quality as well as realizing higher quantity of harvested fodder. This may in turn reduce methane emission risks from enteric fermentation processes.

About $95 \%$ of the respondents who used supplementary feeding/concentrates in Ms rations reported stabilized milk production especially during extreme drought episodes. About $98 \%$ of the surveyed households, however were un-aware of balanced Ms/residues based ration formulation as dry season feeing strategy. This is attributed to inadequate extension education on feed compounding, feeding rates and fodder requirements planning. Importantly, farmers who used concentrates in Ms rations had a drop of less than $20 \%$ (relative to Napier) in milk production while those without supplementation had 50-70 \% drop in production during extreme dry weather spells. The drop in milk production for Ms supplemented rations may be attributed to in-adequate levels of the supplements noted in sampled households. About $95 \%$ of the respondents using supplements, irrespective of production level, rationed the level of concentrate at less than $1 \mathrm{~kg} \mathrm{cow}^{-1} \mathrm{day}^{-1}$. The farmer practices though being nutritionally sub-optimal are rational, in the face of prevailing financial and market risks. Such practices are reflective of farmers' rational decision making on production risk management.

Table 2: Constraints in adapting dairy feeding strategies (\%)in Bungoma and Kakamega counties

Constraint

Shortage of Labour $\quad 23$

Maize Zone Mean

\begin{tabular}{cll} 
Sugarcane Zone & Maize Zone & Mean \\
$\mathrm{N}=221$ & $\mathrm{~N}=179$ & $\mathrm{~N}=400$ \\
\hline
\end{tabular}

Lack of capital( credit) $\quad 55$

Lack of information on 75

36

60

55
29.5

57.5

65 
alternative strategies

$\begin{array}{llll}\text { No barriers } & 2 & 5 & 3.5 \\ \text { Low and unstable prices } & 75 & 92 & 83.5 \\ \text { Others } & 4 & 6 & 5 \\ \text { Land shortage } & 82 & 85 & 83.5\end{array}$

Source: Authors Field data Analysis

\subsection{Methane emissions and Dairy feeding strategies}

The livestock, agriculture and forestry sectors as the largest GHG emitters in Kenya account for approximately $67 \%$ of emissions, with livestock sub-sector contributing about $90 \%$ of the emissions from AFOLU (G.o.K, 2017). The GHG emissions are expected to rise, consistent with a growing population and expanding economy, with emissions increasing from 73 million tons of carbon dioxide equivalent (MtCO2e) in 2010 to 143 MtCO2e in 2030 (G.o.K, 2017). The observation is critical in that maladaptation, moreso the use of Ms without and/ or suboptimal supplementation levels coping strategies as a result of market risks are common (Volenzo, Odiyo, \& Obiri, 2019). Supplementary file (SP1) provides the simulated methane emissions from various adaptation strategies in dairy feeding. In the simulation, Ms has the highest upper limit emission levels at $26 \mathrm{Mj} / \mathrm{kg}$. The emissions reduce with progressive supplementation with farm grown napier and legume fodder.

Though the highest $\mathrm{CH} 4$ mitigation effect in the dairy feeding strategies is from external inputs, such effect is not significantly different $(p \leq 0.05)$ when the effect of farm grown legume fodder such as leuceana spp, Desmodium and sesbania is taken into account. In effect farm produced legume fodder .i.e. dairy-agroforestry and regenerative agricultural systems could be as effective in the mitigation of ruminant related GHG emissions. However the adoption of legume fodders are extremely low at around $1 \%$ of the surveyed households (Table 1). About $84 \%$ of the farmers attributed this to competition between food crops and fodder production objectives as a result of limited land holdings. Evidently there is need for enabling policy for CSA business models, incentives and finance for scaling up CSA (Solomon et al., 2018).This includes the adoption of vertically integrated cooperatives to sustainably address the pervasive price and market risks and ultimately deepen GHG emission mitigation

Supplementary File(1): Simulated Methane emissions from dairy cattle feeding strategies

Supplementary File 2 (SP2), provides variation of prices for various feeding strategies. The locally available dairy feed resources have the lowest cost and price variance over seasons hence low price risks as compared to external resources such as cotton seed cake (CSC) and highly significant at ( $\mathrm{p} \leq$ 0.05). The highest price variance is apparent in feeding strategies that have highest impact on $\mathrm{CH}_{4}$ mitigation while the lowest variance is in the local resource such as Ms, which also have the highest methane emission potential. The price variation hence market risks are significant $(P \leq 0.05)$. In the study area majority of the farmers tended to exclusively rely on Ms as a risk management strategy, a response that is attributed to the significant market and price risks. Such strategies increase methane emissions by up to $30 \%$ per unit of milk produced (Volenzo et al., 2019).

SP 2: Effect of output price variations on risk management at different supplementation levels of basal diets on Gross Margin

Table (3) provides variance in prices in the main dairy feeding strategies in the study area. The mean production price for local resource, Ms is Kes 3.2 against 17.9 for external input supplemented strategy. The variance in price is representative of risk levels and is significant across the various feeding strategies. The highest variance is noted in external input supplemented strategies. This is in contrast to very low variance hence low market and price risks in the locally available feed resources. 
Table 3: Interplay of weather variability and price risks in dairy feeding strategies

\begin{tabular}{llll}
\hline Feeding strategies & \multicolumn{1}{c}{ Sum } & \multicolumn{1}{c}{ Mean } & Variance \\
\hline $\mathrm{Ms}$ & 25.42731 & 3.1784138 & 7.50663259 \\
$\mathrm{Ms}+\mathrm{L}$ & 57.91576 & 7.2394698 & 34.5475737 \\
$\mathrm{Ms}+\mathrm{Cs}+\mathrm{M}$ & 61.871 & 7.733875 & 40.508577 \\
$\mathrm{NaP}$ & 103.9636 & 12.995448 & 129.364698 \\
$\mathrm{Nap}+\mathrm{L}$ & 43.52767 & 5.4409587 & 16.5573137 \\
$\mathrm{Nap}+\mathrm{csc}+\mathrm{M}$ & 85.59153 & 10.698941 & 84.9298324 \\
Ms+Nap & 43.12944 & 5.3911801 & 16.1476138 \\
Ms+Nap+csc & 126.1856 & 15.7732 & 194.706271 \\
Ms+Nap+Csc+Nap & 143.54 & 17.9425 & 254.540736 \\
\cline { 2 - 4 }
\end{tabular}

Source:

Source : Authors calculation based on field survey data among resource constrained farmers, 2019. Nap= Napier

\subsection{Eco-efficiency}

Externalities provide a case study where scope mismatches, sustainability, coherence, integration and sectoral focus in climate adaptation policy could converge. According to Wekesa et al., (2018), the cost of CSA technology constrain small scale farmers' adoption of technologies that have positive potential on environmental sustainability. Table (4) provides the effect of various dairy feeding strategies on ecoefficiency. The effect of resource integration or integrated production is apparent in the effect of various feeding strategies on ecoefficiency. The lowest ecoefficiency is in dairy feeding resources that rely on local coping mechanisms represented by Maize Stover( Ms) at $3.34 \pm 6.79$. Evidently, the highest ecoefficiency is in feeding strategies that utilise external resources but which are highly vulnerable to price shocks at $20.39 \pm 276.78$. The variation between ecoefficiencies in all the feeding strategies are significant $(p=0.05)$. This is of policy relevance on the account variance in the price of external inputs is a source of risk to small scale farmers yet they are critical in dairy productivity and GHG mitigation.

Table 4: comparison of Ecoefficiency between various dairy feeding strategies

\begin{tabular}{|l|c|c|c|}
\hline \multicolumn{1}{|c|}{ SUMMARY } & & & \\
\hline \multicolumn{1}{|c|}{ Feeding strategies } & Sum & Mean Eco. Eff. & Variance \\
\hline $\mathrm{Ms}$ & 30.02501149 & 3.336112388 & 6.792123135 \\
\hline $\mathrm{Ms}+\mathrm{L}$ & 73.41963411 & 8.157737123 & 37.81806142 \\
\hline $\mathrm{Ms}+\mathrm{Cs}+\mathrm{M}$ & 78.53766667 & 8.726407407 & 44.31109005 \\
\hline $\mathrm{NaP}$ & 132.740564 & 14.74895156 & 140.8670766 \\
\hline $\mathrm{Nap}+\mathrm{L}$ & 54.70085363 & 6.077872626 & 18.13858411 \\
\hline $\mathrm{Nap}+\mathrm{csc}+\mathrm{M}$ & 109.1209412 & 12.12454902 & 92.60482285 \\
\hline Ms+Nap & 54.17916464 & 6.019907182 & 17.68684163 \\
\hline Ms+Nap+csc & 161.2733193 & 17.9192577 & 211.8180597 \\
\hline Ms+Nap+Csc+Nap & 183.54 & 20.393333333 & 276.7824 \\
\hline
\end{tabular}




\subsection{DISCUSSION}

\subsection{Measures of effectiveness in climate policy}

In policy, effectiveness or implementation success is largely based on delivery of goods and services from policy effort (Dupuis \& Knoepfel, 2013; Biesbroek et al.,2010). As global commons engender rights and responsibilities, collective action provide appropriate solution space for the management of externalities, which are invariably intertwined with individual preferences and motivations (Folke, Pritchard, Berkes, Colding, \& Svedin, 2007). Such philosophy is visualised as collective effort for mitigating GHG externalities through decarbonisation or green growth pathways initiatives (Otto et al., 2020; Vuuren et al., 2017). Solution of scale problems, such as GHG mitigation and environmental externalities is however undermined by free riding and isolation paradox dilemmas (Burch et al., 2019) that weakens incentives for individual action. This may require a focus on principles that transcend accountability and inclusiveness (Weitz et al., 2017). Since effective local responses (UN, 2019; IPCC 2019; UNFCCC, 2018), are just as important as global strategy .i.e. on sustainability and GHG emission mitigation (Jiménez et al., 2020, UN, 2019; Rey et al., 2017; World Bank, 2014), a focus on voluntary pledge and critical mass or collective action are necessary for a 50\% decrease emissions in by 2050 and less than $2^{\circ} \mathrm{C}$ rise in temperature required for a stable climate (UNFCCC, 2018). This highlights the role and criticality of local- global policy initiatives in implementation success or effectiveness (Otto et al., 2020). Since individual action is a function of agent attributes (Ness et al., 2010) and critical to collective action (Adger et al., 2006) and scale outcomes (Barreteau et al., 2020; Burch et al., 2019), a focus on micro and macro factors influencing societal and environmental management outcomes (Ehara et al., 2018), emerges as integral to the management of spillovers ( Liu et al., 2018)

Though effectiveness by default refers to the extent to which various policy instruments and committed resources contribute to the achievement of a policy goal (Mees et al., 2014), the intended and unintended effects or implementation deficit which is a function of policy coherence and integration accurately reflect success or effectiveness of policy effort (Dupuis Knoepfel, 2013). Table 3 summarises how effectiveness is contextualised in existing literature. Effectiveness includes the extent to which climate action and policies focus and address underlying causes, such as shifting vulnerabilities and land degradation (IPCC, 2019), as well as internal processes of change at individual, organizational and technological level (Otto et al., 2020; Pelling et al., 2015). It also involves the linking of disaster risk reduction to climate risk management, adaptation through better land use and resource based approaches (UNISDR, 2015b). According to (Nalau \& Handmer, 2015), effectiveness relates to policy focus on the significant dimension of the problem, hence the extent of implementation as reflected by numbers, range and scale. Since (I)NDCS provide an opportunity for inclusivity, we explored how this can be realised in adaptation planning. The definition and conceptualisation is critical in view of adaptation emissions and the emergent issue of shifting vulnerabilities (Barreteau et al., 2020; Adger and Winkel, 2009). 
Table 4: contextualisation of effectiveness as used in climate policy literature

\begin{tabular}{|c|c|c|c|c|}
\hline $\begin{array}{l}\text { Dimension of } \\
\text { Effectiveness }\end{array}$ & Rationale & Specification in literature & $\begin{array}{l}\text { Challenges and causes } \\
\text { of dissonance }\end{array}$ & References \\
\hline Collective Action & $\begin{array}{l}\text { Cross-scale } \\
\text { Efficiency } \\
\text { Free riding } \\
\text { Individual action as } \\
\text { insufficient }\end{array}$ & $\begin{array}{l}\text { Critical mass } \\
\text { Inclusivity and responsibility } \\
\text { Voluntarism } \\
\text { Participation }\end{array}$ & $\begin{array}{l}\text { Legitimacy } \\
\text { Dualism in framing } \\
\text { Subsidiarity } \\
\text { and attribution }\end{array}$ & $\begin{array}{l}\text { (Weitz et al., 2017; Adger 2006; Milkoreit et } \\
\text { al., 2018; Nalau \& Handmer, 2015;IPCC, } \\
\text { 2019; UN, 2019; UN, 2015a; UNFCC, 2018; } \\
\text { Park et al., 2012; Gordon et al., } \\
\text { 2015;Walthall et al., 2012;Smith \& Mayer, } \\
\text { 2018;Adger, } 2003\end{array}$ \\
\hline Integration & $\begin{array}{l}\text { Resource mobilisation } \\
\text { Synergy } \\
\text { Complementarity }\end{array}$ & $\begin{array}{l}\text { Integrated Resource Management ( in } \\
\text { agriculture as integrated farming } \\
\text { technologies), Mainstreaming } \\
\text { Multidisciplinary } \\
\text { Policy coherence } \\
\text { Nested/ Coupled/Holistic domains } \\
\text { Social Ecological system (SES) } \\
\text { Human- Environment System (H-E-S ) }\end{array}$ & $\begin{array}{l}\text { Decision tools for } \\
\text { operationalisation } \\
\text { Cognitive failure among } \\
\text { actors } \\
\text { Coordination failures } \\
\text { Segmented project and } \\
\text { programme mandates } \\
\text { Governance structure }\end{array}$ & $\begin{array}{l}\text { Nalau \& Handmer, 2015; Dupuis \& } \\
\text { Knoepfel, 2013, Massey \& Huitema, 2013; } \\
\text { Biesbroek et al., 2010; Burch et al., 2019; } \\
\text { Mees et al., 2014; Xu et al., 2015; Naess et } \\
\text { al., 2015;Weitz et al., 2017;Ness et al., } \\
\text { 2010;Nelson et al., 2007; Shimon et al., } \\
\text { 2017; Wekesa et al., 2018; Chesterman \& } \\
\text { Neely, } 2015\end{array}$ \\
\hline Transformation & $\begin{array}{l}\text { Addressing underlying } \\
\text { causes by focusing on } \\
\text { Values and goals }\end{array}$ & $\begin{array}{l}\text { Social transitions } \\
\text { Participatory planning } \\
\text { Diffusion and adoption }\end{array}$ & $\begin{array}{l}\text { Policy problematisation } \\
\text { Cognitive failure and } \\
\text { fragmentation } \\
\text { Project and mandates }\end{array}$ & $\begin{array}{l}\text { Pelling et al., 2015; O’Brien, 2012; Nalau \& } \\
\text { Handmer, 2015; IPCC, 2014; Rogers, 2004; } \\
\text { Massey \& Huitema, 2013;Massey et al., } \\
\text { 2014;Ness et al., } 2010\end{array}$ \\
\hline Externalities & $\begin{array}{l}\text { Comprehensive risk } \\
\text { assessment on ecology } \\
\text { and economic linkages } \\
\text { in decision making } \\
\text { Collective hazard } \\
\text { management }\end{array}$ & $\begin{array}{l}\text { Shifting vulnerabilities } \\
\text { Diffuse effects/flows/Leakages } \\
\text { Environmental accounting } \\
\text { IRM }\end{array}$ & $\begin{array}{l}\text { Integration of decision } \\
\text { tools i.e. SEAs/ EIAs/RIA } \\
\text { incentive system } \\
\text { Risk denial } \\
\text { Layered agents and } \\
\text { coordinated responses at } \\
\text { scale } \\
\text { Delimiting the boundary }\end{array}$ & $\begin{array}{l}\text { Ness et al., 2010; Nalau \& Handmer, 2015; } \\
\text { Suckall et al., 2014; Liu et al., 2018; Naess } \\
\text { et al., 2015; Burch et al., 2019, Adger, } \\
\text { Eakin, \& Winkels, 2009; Barreteau et al., } \\
\text { 2020;Vammen et al., 2012; Jordan et al., } \\
2013\end{array}$ \\
\hline
\end{tabular}

Key: IRM (Integrated Risk Management); RIA, Regulatory Impact Assessment; SEA, Strategic Impact Assessment; EIAs, Environmental Impact Assessments 
As global climate policy is premediated on the principle of common but differentiated responsibility and capability (UN, 2019;UN, 2015a), voluntary ecosystem based collective action are preferable in the management of environmental externalities (Ness et al., 2010). Addressing the weak links, hence attention to voluntary mechanisms as alternative to regulatory and/ or enforcement could enhance effectiveness in managing externalities (Ness et al., 2010).This includes the identification and prioritisation of risk management strategies and shared action between private action and public sectors action across scale where risk chain can be visualised in terms of shocks, internal and external drivers, their management and outcomes (World Bank, 2014). Responses for risk management, however are poorly addressed (Eakin et al., 2014). In most responses are based on BAU models (Milkoreit et al., 2018;Nalau \& Handmer, 2015).

In synthesis of existing literature (Fig.2), the role of risk as an attribute of decision making at micro level impacts GHG emissions on global GHG spillover system is suggested. Adaptation policy is a thus confluence of internal, as well as internal drivers, both of which are critical drivers in decision making and effectiveness of climate change action (Ampaire et al., 2017; Massey et al., 2014). Accordingly, there is need for critical reflexivity to manage internal processes of change at individual, organizational and technological level, which are key to addressing transformative agenda (Otto et al., 2020; Young, 2006; Pelling et al., 2015). The role of risk which informs our article, however has not been given a nuanced analysis in multilateral intervention targeting net zero carbon economies. Since the realisation of net zero emissions by 2050 (UNFCCC, 2018; UN, 2015a), is underpinned by collective action, an element of critical mass, resolution of functional or scope challenges in Human- Environment (H-E) systems (Otto et al., 2020; Steffen et al., 2018; Folke et al., 2007), and delivery of programmes and projects are some of the policy innovations in pursuit of effectiveness (Dupuis \& Knoepfel, 2013). We thus framed effectiveness in terms of impactful collective action effort that enhances synergies between adaptation and mitigation. The reflective advancement model narrows existing gaps on how to incentivise local level action for effective climate action.

Integrated approaches are recommended in institutional-cognitive interlays and environmental risk assessments (Shimon et.al., 2017). Incorporating externalities into decision making as a policy concern (Hulina et.al., 2017; Sikor, He, \& Lestrelin, 2017) could be achieved through informal i.e. taxation and formal institutions i.e. private certification schemes (Liu et al., 2018; Zimmerer et al., 2018). This includes the use of conventional policy instruments such as subsidies or taxes to shape farmer support for international ecological initiatives and international agreements (Lewis et al., 2008). The uptake of ideas and technology by agents, such as individual farmers, is accounted through diffusion of technology models which is a reflection of decision making (Rogers, 2004). Risk plays a key role in decision making, such as uptake of technology (idea) or otherwise (Koundouri et al., 2019). As adaptive capacity, is an interplay of price, institutions and policies (FAO, 2010; UNEP, 2011), they are also integral role in risk management. In our case study, the cost of dairy feeds is critical to decision making in weather related dairy cattle feeding risk management and GHG emissions.

In synthesis of existing literature (Fig.2), the role of risk as an attribute of decision making at micro level impacts GHG emissions on global GHG spillover system is suggested. Adaptation policy is a thus confluence of internal, as well as internal drivers, both of which are critical drivers in decision making and effectiveness of climate change action (Ampaire et al., 2017; Massey et al., 2014). Accordingly, there is need for critical reflexivity to manage internal processes of change at individual, organizational and technological level, which are key to addressing transformative agenda (Otto et al., 2020; Young, 2006; Pelling et al., 2015). The role of risk which informs our article, however has not been given a nuanced analysis in multilateral intervention targeting net zero carbon economies. Since the realisation of net zero emissions by 2050 (UNFCCC, 2018; UN, 2015a), is underpinned by collective action, an element of critical mass, resolution of functional or scope challenges in Human- Environment (H-E) systems (Otto et al., 2020; Steffen et al., 2018; Folke et al., 2007), and delivery of programmes and projects 
are some of the policy innovations in pursuit of effectiveness (Dupuis \& Knoepfel, 2013). We thus framed effectiveness in terms of impactful collective action effort that enhances synergies between adaptation and mitigation. The reflective advancement model narrows existing gaps on how to incentivise local level action for effective climate action.

Externalities or Shifting vulnerabilities as unintended consequence of one actors' acts of omission or commission increases predisposition to harm on a third party in interdependent systems and processes (Barreteau et al., 2020). Shifting vulnerabilities are visualised as flows as analysed through telecoupling lenses thus presents a strong heuristic lens for examining and describing distal causal relations in land-use (Friis \& Nielsen, 2017). Accordingly, parcel-level land-use decisions may aggregate to influence landscape-scale processes, spatial externalities and provisioning of public goods at the regional scale, such as sediment flows in watersheds and the global scale (Lewis et al., 2008). Spillover systems can thus be used to analyse the effectiveness of H-E system and their interplay at local to global scales (Parish et al., 2018; Xiong et al., 2018). In light of sustainability lenses, the assessment of the extent of externalities or maladaptive practice as proxy for externalities and how they are accounted for (Suckall, Tompkins, \& Stringer, 2014; Ness et al., 2010) is one of the critical area in CPI.

Transformative lenses to a large extent refer to how different management approaches innovatively deal with a particular problem (Nalau \& Handmer, 2015). It includes the embedding of sustainability lens into analysis as to avoid ambiguity and support novel decision making (Pelling et al., 2015; Wise et al., 2014). Combining metacoupling and DPSIR could provide a comprehensive risk assessment tool that links internal and external factors (Xu et al., 2015), as well as assessing the potential impact in decision making. By combining DPSIR and telecoupling, we offer an improved analytical framework tool for CPI innovation and inclusive multilaterism to assess effectiveness in climate policy and scale up GHG mitigation partnerships. The tool can be utilised in formal and informal governance instruments, such as programming eco-certification schemes, resolving the problem of dualism in adaptation- mitigation polices and duplication in programing. The robust analytical and conceptual framework thus has potential for reflective policy design, performance assessment and review performance in CPI frameworks.

Coordinated multisectoral programming, implementation and monitoring in adaptation planning can be achieved through use of integrated risk management (IRM) approaches ( Xu et al., 2015; World Bank, 2014). An IRM model in Fig 2, captures the centrality of risk, values and beliefs as cognitive factors that undermine policy objectives (c.f. Kuruppu \& Willie, 2015). The IRM hereustic is critical for reflective advancement on effective collaboration mechanisms between local and global actors i.e. evaluating climate risks and policy opportunities that address pervasive constraints, such as the duplication of projects and programmes and shifting vulnerabilities. In essence policy innovation need to consider and integrate the interplay between scope and functional fit variables such as motivations and preferences of the primary actors, in essence the centrality of risk dimension as critical component in agent decision making (Weitz et al., 2017; Kuruppu \& Willie, 2015). Our model on risk lens in decision making contributes to CPI by addressing the role of decision making gaps on externalities.

Though Western Kenya is an idiosyncratic case in global climate policy agenda, it provides invaluable insights on scope, functional and temporal mismatches and ultimately CPI and coherence from resilience perspective. In particular it is relevant from the emerging issue of shifting vulnerability and global common dilemmas. The limitation of our study mainly lies in the methodology which may under-estimate or over-estimate emission levels. The higher emission limits from the simulation were however relied on as to inform disaster risk reduction. Such quantification of the risks backed by agent data perspectives, improves on the weaknesses in the ubiquitous descriptive telecoupling models (Xiong, Millington, \& Xu, 2018), close the gaps on the interplay between agent decision making and environmental externalities. 

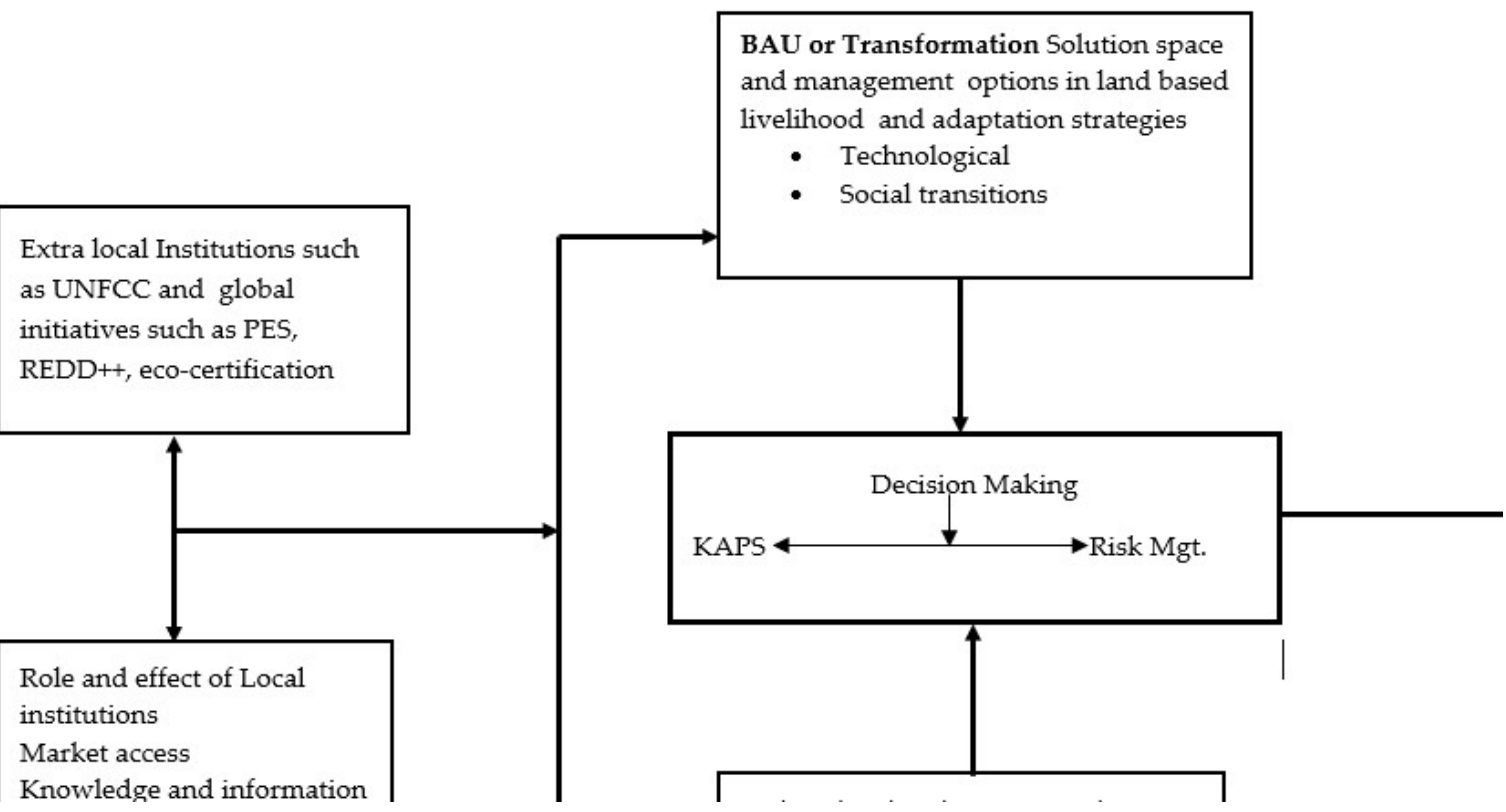

Fig. 2 : A heuristic on the centrality of risk in decision making at local level, environmental externalities and effectiveness of global- local action for effective climate policy, adaptation and GHG mitigation. Kaps (knowledge, Attitude and Practices or Behaviour) which affect risk management(Mgt.) are critical and integral to individual and collective decision making and ultimately GHG effect

\subsection{Conclusions}

Adjusting to climate change related risks largely depend on transforming agriculture and food systems to deepen food security, alleviate poverty, enhance adaptation-mitigation synergies and ultimately effective climate action. Building synergies and shared action between private action and public sectors across scale which to a great extent depend on policy and organizational coherence, is thus a prerequisite in managing the embedded shifting vulnerabilities, environmental and other sustainability problems in the transformation process. However, in agrobased economies where adaptation to climate change risks is an urgent need, its contribution in closing GHG emission gaps is accorded low attention in climate change mitigation agenda. This article has suggested a scheme that combines two analytical policy tools, DPSIR and telecoupling in examining the visualisation of externalities into climate policy discourses. The purpose has been to provide a tool for reflective advancement in climate policy innovation. The scheme is contextualised in terms of the pervasive adaptation-mitigation dualism and scope challenges in mainstreaming externalities into adaptation planning. The article has framed the deepening GHG effect, as a global common challenge whose diffusion across scale reflect global interconnectivity of socioecological systems. The study underscores the utility of complementarity lenses and framing as the logical basis for the prioritisation and optimisation of adaptation-mitigation synergies in climate action initiatives and the resolution of pervasive adaptation-mitigation dualism. Of equal importance is the role and the need for policy and organisational coherence which have the potential to address duplication in climate action programming.

\section{REFERENCES}

Adger, W. N. (2003). Social Capital, Collective Action, and Adaptation to Climate Change. Economic Geography, 79(4), 387-404. Retrieved from http://www.clarku.edu/econgeography

Adger, W. N., Arnell, N. W., \& Tompkins, E. L. (2005). Successful adaptation to climate change across scales. Global Environmental Change, 15(2005), 77-86. https://doi.org/10.1016/j.gloenvcha.2004.12.005 
Adger, W. N., Eakin, H., \& Winkels, A. (2009). Nested and teleconnected vulnerabilities to environmental change. Front Ecol Environ, 7(3), 150-157. https://doi.org/10.1890/070148

Altieri, M.A., Nicholls, C.I., Henao, A. and Lana, M.A( 2015). Agroecology and the design of Climate- resilient farming systems. Agron.Sustain.Dev 35: 869-890.Doi 10.1007/s13593-1050285-2

Ampaire, E. L., Jassogne, L., Providence, H., Acosta, M., Twyman, J., Winowiecki, L., \& Asten, P. (2017). Institutional challenges to climate change adaptation: A case study on policy action gaps in Uganda. Environmental Science and Policy, 75, 81-90. https://doi.org/10.1016/j.envsci.2017.05.013

Barreteau, O., Anderies, J., Guerbois, C., Quinn, T., Therville, C., \& Mathevet, R. (2020). Transfers of vulnerability through adaptation plan implementation: an. Ecology and Society, 25(2), 3-19. https://doi.org/https://doi.org/10.5751/ES-11402-250203

Bebe, B.O., Rademaker,C., Lee, v-d.J , Kilelu,C and Tonui, C ( 2016). Sustainable growth of

the Kenyan dairy sector - A quick scan of robustness, reliability and resilience. Wageningen, Wageningen \& Research centre, Netherlands(http://dx.doi.org/10.18174/413390

Becx, G. A., Mol, G., Eenhoorn, J. W., Kamp, J. D., \& Vliet, J. V. (2012). Perceptions on reducing constraints for smallholder entrepreneurship in Africa : the case of soil fertility in Northern Ghana. Current Opinion in Environmental Sustainability, 4(5), 489-496. https://doi.org/10.1016/j.cosust.2012.10.012

Bharwani, S., Bithell, M., Downing, T., Mark, N., Washington, R., \& Ziervogel, G. (2005). Multi-agent modelling of climate outlooks and food security on a community garden scheme in Limpopo, South Africa. Philosophical Transactions: Bio .Sci, 2183-2194. https://doi.org/10.1098/rstb.2005.1742

Biesbroek, G. R., Swart, R. J., Carter, T. R., Cowan, C., Henrichs, T., Mela, H., ... Rey, D. (2010). Europe adapts to climate change : Comparing National Adaptation Strategies. Global Environmental Change, 20(3), 440-450. https://doi.org/10.1016/j.gloenvcha.2010.03.005

Burch, S., Gupta, A., Inoue, C., Kalfagianni, A., Persson, Å., Gerlak, A., ... Zondervan, R. (2019). New directions in earth system governance research. Earth System Governance, 1(100006), 1-18. https://doi.org/10.1016/j.esg.2019.100006

Calvin, K., \& Bond-lamberty, B. (2018). Integrated human-earth system modeling - state of the science and future directions OPEN ACCESS Integrated human-earth system modeling - state of the science and future directions. Environ. Res. Lett., 13(063006).

https://doi.org/https://doi.org/10.1088/1748-9326/aac642

Chesterman, S., \& Neely, C. (2015). implications of Climate- Smart Agriculture in Kenya (Research Program on Climate Change, Agriculture and Food Security (CCAFS) No. 90). Copenhagen, Denmark. Retrieved from www.ccafs.cgiar.org

Debala,E.,Tolera,A.,Eik,O.L., and Salte,R.(2011).Nutritive value of Morphological Fractions of Sesbania sesban and Desmodium intortum.Trop. and SubTrop Agroecos.14 (2011), 793-805

Di Gregorio, M., Ridho, D., Paavola, J., Maya, I., Fatorelli, L., Pramova, E., ... K, D. S. (2017). Climate policy integration in the land use sector : Mitigation, adaptation and sustainable development linkages. Environmental Science and Policy, 67, 35-43. https://doi.org/10.1016/j.envsci.2016.11.004

Downing, T.E and Patwardhan, A. (2002).vulnerability assessment for Climate Change adaptation. Planning Framework Technical paper 3.SEI, Oxford

Dupuis, J., \& Knoepfel, P. (2013). The Adaptation Policy Paradox : the Implementation Deficit of Policies. Ecology and Society, 18(4), 31-47

Dzowela, B.H, (1985).Value of forage legume component in summer beef fattening systems in 
Malawi. Paper presented at the Workshop on potentials of Forage Legumes in Farming systems of Sub Saharan Africa 16-19th September, 1985 Addis Ababa, Ethiopia.

Eakin, H. C., Lemos, M. C., \& Nelson, D. R. (2014). Differentiating capacities as a means to sustainable climate change adaptation. Global Environmental Change, 27, 1-8. https://doi.org/10.1016/j.gloenvcha.2014.04.013

Ellis,J.L.,Kebreab,E.,Odongo,N.E.,McBride,B.W.,Okine,E.K.and France, F (2007).Prediction of methane production from Dairy and beef cattle. J. of Dairy Sci. 90, 3456-3467

Ehara, M., Hyakumura, K., Kurosawa, K., \& Araya, K. (2018). Addressing Maladaptive Coping Strategies of Local Communities to Changes in Ecosystem Service Provisions Using the DPSIR Framework. Ecological Economics, 149, 226-238. https://doi.org/10.1016/j.ecolecon.2018.03.008

Elias, E., Laband, D., Dougherty, M., Lockaby, G., Srivastava, P., \& Rodriguez, H. (2014). The Public Water Supply Protection Value of Forests : A Watershed-Scale Ecosystem Services Analysis Based upon Total Organic Carbon. Open Journal of Ecology, 517-531. https://doi.org/Published Online June 2014 in SciRes. http:// http://dx.doi.org/10.4236/oje.2014.49042

FAO. (2010). “Climate-Smart" Agriculture: Policies, Practices and Financing for Food Security, Adaptation and Mitigation. Rome, Italy. Retrieved from www.fao.org/climatechange

FAO. (2017). Regional analysis of the nationally determined contributions of eastern africa: Gaps and opportunities in the agriculture sector (Environment and Natural Resource Management No. 67). Rome, Italy. Retrieved from www.fao.org/publications

FAO. (2019). The future of livestock in Kenya: Opportunities and Challenges in the face of uncertainity. Rome, Italy. Retrieved from www.fao.org/publications

Folke, C., Pritchard, L., Berkes, F., Colding, J., \& Svedin, U. (2007). The Problem of Fit between Ecosystems and Institutions : Ten Years Later. Ecology and Society, 12(1), 30-65.

Gebrehawariat, E., Tamir, B and Tegegne, A. (2010).Feed intake and production parameters of lactating crossbred cows fed maize-based diets of Stover, silage or quality protein silage.Trop .Anim Health Prod. 42(8): 1705-1710

G.o.K. (2007). Kenya Vision 2030 . Towards a globally competitive and prosperous Kenya. Nairobi, Kenya. Retrieved from http://go.ke

G.o.K. (2010). National Climate Change Response Strategy. "Together we can tackle climate change". Nairobi, Kenya.

G.o.K. (2017). Kenya Climate Smart Agriculture Strategy 2017-2016. Nairobi, Kenya. Retrieved from www.Kilimo.go.ke

G.o.K. (2018). Climate Change Action Plan 2018-2022 (Vol. I). Nairobi, Kenya. Retrieved from website: www.environment.go.ke

G.o.K. (2019). Agricultural Sector Transformation and Growth Strategy 2019-2029. Nairobi, Kenya.

G.o.K. (2015). Kenya's Intended Nationally Determined Contribution ( INDC ). Nairobi, Kenya. Geber, P., Steinfeld, H., Henderson, B., Mottet, A., Opio, C., Dijkman, J., ... Tempio, G. (2013). Tackling Climate change through livestock: a global assessment of emissions and mitigation opportunities. (P. . Geber, H. Steinfeld, B. Henderson, A. Mottet, C. Opio, J. Dijkman, ... G. Tempio, Eds.). Rome, Italy: $\mathrm{FAO}$ (Food and Agriculture Organisation of the United Nations). Retrieved from http://www.fao.org/../i3437e00.htm

Gorddard, R., Colloff, M. J., Wise, R., Ware, D., \& Dunlop, M. (2016). Values , rules and knowledge: Adaptation as change in the decision context. Environmental Science and Policy, 57, 60-69. https://doi.org/10.1016/j.envsci.2015.12.004

Hall, P. A. (1993). Policy Paradigms, Social Learning, and the State: The Case of Economic Policymaking in Britain. Comparative Politics, 25(3), 275-296. Retrieved from 
https://www.jstor.org/stable/422246

Helgeson, J. F., Dietz, S., \& Hochrainer-stigler, S. (2013). Vulnerability to Weather Disasters : the Choice of Coping Strategies in Rural Uganda. Ecology and Society, 18(2), 2-15. https://doi.org/http://dx.doi.org/10.5751/

Hirooka, H (2010).Systems approaches to beef cattle production systems using modelling and simulation. Anim. Sci. journal 81:411-424.

Hopkins, D. (2014). The sustainability of climate change adaptation strategies in New Zealand's ski industry : a range of stakeholder perceptions. Journal of Sustainable Tourism, 22(1), 107-126. https://doi.org/10.1080/09669582.2013.804830

Hulina, J., Bocetti, C., Iii, H., Hull, V., \& Yang, W. (2017). Telecoupling framework for research on migratory species in the Anthropocene. Elem Sci Anth, 5, 5. https://doi.org/DOI: https://doi.org/10.1525/elementa.184

Hull, V., \& Liu, J. (2018). Telecoupling : A new frontier for global sustainability. Ecology and Society, 23(4), 41-50. https://doi.org/https://doi.org/10.5751/ ES-10494-230441

Ingram, H., Schneider, A.L. and Deleon, P. (2007). Social Construction and policy design. Theories of the Policy Process 2, 93-126

IPCC. (2006). Emissions from Livestock and Manure Management. In Guidelines for National Greenhouse Inventories. Zurich, Switzerland: IPCC Secretariat.

IPCC. (2014). Climate change: Impacts, Adaptation and Vulnerability. The fifth Assessment Report of IPCC (Eds. Field, C.B. et al). Cambridge University Press, UK and Newyork.

IPCC ( Inter Governmental Panel on Climate Change. (2019). Climate Change and Land: An IPCC Special Report on climate change, desertification, land degradation, sustainable land management, food security, and greenhouse gas fluxes in terrestrial ecosystems. Summary for Policy Makers.

Jaetzold, R., Schmidt, H., Hornetz, B., \& Shisanya, C. (2011). Farm Management Handbook of Kenya Vol 11- Natural Condtions and Farm Management Information. Second Edition. Part II/A1(western Kenya) and Part II/CI(Eastern Province) (Vol. II). Nairobi, Kenya: Ministry of Agriculture, Kenya/GTZ.

Jiménez, A., Garry, A., Albert, D. P., Grace, V. N., \& Andrea, Y. W. (2020). Local lens for SDG implementation : lessons from bottom - up approaches in Africa. Sustainability Science, 15(3), 729743. https://doi.org/10.1007/s11625-019-00746-0

Jordan, A., Rayner, T., Schroeder, H., Adger, N., Anderson, K., Bows, A., ... van Isselt, J. W. (2013). Going beyond two degrees? The risks and opportunities of alternative options opportunities of alternative options. Climate Policy, 13(6), 751-769.

https://doi.org/10.1080/14693062.2013.835705

KDB(2020). Kenya Dairy Board. Dairy data online portal. www.kdb.co.ke. Accessed 27th October, 2020

KNBS. (2017).Kenya National Bureau of Statics. Economic Survey. Nairobi, Kenya. Retrieved from http://www.knbs.or.ke

KNBS. (2019). Kenya National Bureau of Statics. 2019 Kenya Population and Housing Census : Counting Our People for Sustainable Development and Devolution of Services (Vol. I). Nairobi, Kenya. Retrieved from www.knbs.or.ke

Knox, M. A., Meinzen-dick, R., \& Hazell, P. (1998). Technologies for Natural Resource Management : CGIAR System-wide Program on Property Rights and Collective Action (No. Working Paper No.1). Property Rights, Collective Action and Technologies for Natural Resource Management: A conceptual Framework. Baltimore and London. Retrieved from http://www.capri.cgiar.org/wp/capriwp01.asp

Koundouri, P., Nauges, C., \& Tzouvelekas, V. (2019). Technology Adoption under Production

Uncertainty: Theory and Application to Irrigation Technology. Amer.j. Agr. Econ, 88(3), 657-670.

Retrieved from https://www.jstor.org/stable/3697756

Kontogianni, A., Skourtos, M., Kapsimalis, V., Kontogianni, A., Skoulikidis, N. T., Pagou, K., ... 
Anagnostou, C. (2005). An integrated approach to watershed management within the DPSIR framework: Axios River catchment and Thermaikos Gulf. Reg Environ Change, 5, 138-160. https://doi.org/10.1007/s10113-004-0078-7

Kuruppu, N., \& Willie, R. (2015). Barriers to reducing climate enhanced disaster risks in Least

Developed Country-Small Islands through anticipatory adaptation. Weather and Climate Extremes, 7, 72-83. https://doi.org/10.1016/j.wace.2014.06.001

Lachapelle, E., Paterson, M., Lachapelle, E., \& Paterson, M. (2013). Drivers of national climate policy. Climate Policy, 13(5), 547-571. https://doi.org/10.1080/14693062.2013.811333

Lemos, M. ., \& Agrawal, A. (2006). Environmental Governance. Annual Review of Environment and Resources, 31(1), 297-325.ttps://doi.org/10.1146/annurev.energy.31.042605.135621

Lewison, R., Rudd, M., Al-hayek, W., Baldwin, C., Beger, M., Lieske, S., ... Hines, E. (2016). How the DPSIR framework can be used for structuring problems and facilitating empirical research in coastal systems. Environmental Science and Policy, 56, 110-119.

Liu, J. (2017). Integration across a metacoupled world. Ecology and Society, 22(4). https://doi.org/https://doi.org/10.5751/ES-09830-220429

Liu, J., Dou, Y., Batistella, M., Challies, E., Connor, T., Friis, C., ... Sun, J. (2018). Spillover systems in a telecoupled Anthropocene : typology, methods, and governance for global sustainability. Current Opinion in Environmental Sustainability, 33, 58-69. https://doi.org/10.1016/j.cosust.2018.04.009

Liu, J., Hull, V., Batistella, M., Defries, R., Dietz, T., Fu, F., ... Naylor, R. (2013). Framing Sustainability in a Telecoupled World. Ecology and Society, 18(2), 26-45. https://doi.org/http://dx.doi.org/10.5751/ ES-05873-180226

Liu, J., Mooney, H., Hull, V., Davis, S. ., Gaskell, J., Hertel, T., ... Li, S. (2015). Systems integration. Sustainability, 347(6225), 963-971. https://doi.org/10.1126/science.1258832

Liu, J., \& Yang, W. (2013). Integrated assessments of payments for ecosystem services programs. PNAS, 110(41), 16297-16298. https://doi.org/10.1073/pnas.1316036110

Loboguerrero, A. M., Campbell, B. M., Cooper, P. J. M., Hansen, J. W., Rosenstock, T., \& Wollenberg, E. (2019). Food and Earth Systems : Priorities for Climate Change Adaptation and Mitigation for Agriculture and Food Systems. Sustainability, 11(1372), 26. https://doi.org/10.3390/su11051372

Makoni, N.F., R. Mwai, T. Redda, A., Zijpp v-d, and Lee, v-d. J (2014). White gold: opportunities fordairy sector development collaboration in East Africa. Report CDI-14-006. Wageningen: Centre for Development Innovation, Wageningen University Research centre

Maredia, M. K., \& Minde, I. J. (2002). Technology, Profitability and agricultural Transformation: Concepts, Evidence and Policy implications. In G. Jayne, T.S., Minde, P.and Argwings-Kodhek, G (Ed.), Perspectives on Agricultural Transformation. A view from Africa (pp. 83116). New York: Nova Science Publishers Inc.

Massey, E., Biesbroek, R., Huitema, D., \& Jordan, A. (2014). Climate policy innovation : The adoption and diffusion of adaptation policies across Europe. Global Environmental Change, 29(2014), 434-443. https://doi.org/10.1016/j.gloenvcha.2014.09.002

Massey, E., \& Huitema, D. (2013). The emergence of climate change adaptation as a policy field : the case of England. Reg Environ Change, 13, 341-352. https://doi.org/10.1007/s10113-0120341-2

Masuda, K. (2016). Measuring eco-efficiency of wheat production in Japan : a combined application of life cycle assessment and data envelopment analysis. Journal of Cleaner Production, 126, 373-381. https://doi.org/10.1016/j.jclepro.2016.03.090

Mcdermott, M., Mahanty, S., \& Schreckenberg, K. (2012). Examining equity : A 
multidimensional framework for assessing equity in payments for ecosystem services.

Environmental Science and Policy, 33, 416-427. https://doi.org/10.1016/j.envsci.2012.10.006

Mees, H. L. P., Dijk, J., Soest, D. V, Driessen, P. P. J., Rijswick, M. H. F. M. W. V, \& Runhaar,

H. (2014). A method for the deliberate and deliberative selection of policy instrument. Ecology

and Society, 19(2). https://doi.org/http://dx.doi.org/10.5751/IES-06639-190258

Meng, B., Peters, G., \& Wang, Z. (2015). Tracing Greenhouse Gas Emissions in Global Value

Chains (No. Working Paper No . 525). Stanford.

Milkoreit, M., Hodbod, J., Baggio, J., Benessaiah, K., Donges, J. F., Mathias, J., ... Schoon, M. (2018). Defining tipping points for social-ecological systems scholarship - an interdisciplinary literature review. Environmental Research Letters, 13(033005). https://doi.org/10.1088/17489326/aaaa75

Mills, J. A. N., Kebreab, E., Yates, C. M., Crompton, L. A., Cammell, S. B., Dhanoa, M. S., ... France, J. (2003). Alternative approaches to predicting methane emissions from dairy cows. J. of Anim. Sci, 81(12), 3141-3150. https://doi.org/10.2527/2003.81123141x

Mills,J.A.,Dijkistra,J.,Bannik.,Cammel,S.B.,Kebreab,E.,France.J.(2001).Amechanistic model of whole tract digestion and methanogenesis in the lactating dairy cow: Model development, evaluation and application. J. of Anim .Sci.2001.79:1584-1597

Muia, J.M.K, Tamminga, S., Mbugua, P.N. and Kariuki, J.N. (1999). Optimal stage of Maturity for feeding napier grass (Pennisetum purpureum) to dairy cows in Kenya.Trop. Grasslands, 33:182-190

Muinga, R.W., Thorpe W. and Topps, J.H. (1995). The effect of supplementation with Leucaena leucophala and maize bran on voluntary food intake, digestibility, Live-weight and milk yield of Bos Indicus $x$ BosTauras dairy cows and rumen fermentation in steers offered Pennisetum purpureum ad-libitum in the semi-humid tropics. Anim. Sci. 60:13-23

Muinga, R.W., Thorpe, $\mathrm{W}$ and Topps, J.H. (1993).Lactational performance of Jersey cows given napier grass ( Pennisetum purpureum) with or without protein concentrates in the semi humid tropics. Trop.Anim. Health and prod. 25: 118-128

Murgueitio, E., Calle, Z., Uribe, F., Calle, A., \& Solorio, B. (2011). Native trees and shrubs for the productive rehabilitation of tropical cattle ranching lands. Forest Ecology and Management, 261(10), 1654-1663. https://doi.org/10.1016/j.foreco.2010.09.027

Naess, O. L., Newell, P., Newsham, A., Phillips, J., Quan, J., \& Tanner, T. (2015). Climate policy meets national development contexts : Insights from Kenya and Mozambique. Global Environmental Change, 35(2015), 534-544. https://doi.org/10.1016/j.gloenvcha.2015.08.015

Nalau, J., \& Handmer, J. (2015). When is transformation a viable policy alternative? Environmental Science and Policy, 54, 349-356. https://doi.org/10.1016/j.envsci.2015.07.022

Nalau, J., Preston, B. L., \& Maloney, M. (2015). Is adaptation a local responsibility? Environmental Science and Policy, 48, 89-98. https://doi.org/10.1016/j.envsci.2014.12.011

Nelson, D., Adger, W. N., \& Brown, K. (2007). Adaptation to Environmental Change : Contributions of a Resilience Framework. Annual Rev. Environ.Resour, 32, 395-419. https://doi.org/10.1146/annurev.energy.32.051807.090348

Niemeijer, D., \& de Groot, R. (2008). Framing environmental indicators : moving from causal chains to causal networks. Environ Dev Sustain, 10, 89-106. https://doi.org/10.1007/s10668-006-9040-9

Ness, B., Anderberg, S., \& Olsson, L. (2010). Structuring problems in sustainability science :

The multi-level DPSIR framework. Geoforum, 41(3), 479-488.

https://doi.org/10.1016/j.geoforum.2009.12.005

Niles, M., Ahuja, R., Barker, T., Esquivel, J., Gutterman, S., Heller, M., ... Vermeulen, S. 
(2018).Climate change mitigation beyond agriculture: A review of food system opportunities and implications. Renewable Agriculture and Food Systems, 33(3), 297-308.

doi:10.1017/S1742170518000029

Nunan, F., Campbell, A., \& Foster, E. (2012). Environmental Mainstreaming : The

Organisational Challenges of Policy Integration. Public Admin. Dev., 32, 262-277. https://doi.org/10.1002/pad

Odhiambo, C. O., Ogindo, H. O., Wasike, C. B., \& Ochola, W. O. (2019). Adaptation of Smallholder Dairy Farmers in South Western Kenya to the Effects of Climate Change. Atmospheric and Climate Sciences, 9(2019), 456-478. https://doi.org/10.4236/acs.2019.93031

Ojeda-Martınez, C., Casalduero, F., Bayle-Sempere, J., Cebria'n, C., Valle, C., Gime, F., ... Brito, A. (2009). Ocean \& Coastal Management A conceptual framework for the integral management of marine protected areas. Ocean and Coastal Mgt., 52, 89-101. https://doi.org/10.1016/j.ocecoaman.2008.10.004

Ostrom, E. (2007). A diagnostic approach for going beyond panaceas. PNAS, 104(39), 1518115187. https://doi.org/10.1073 pnas.0702288104

Otto, I. M., Donges, J. F., Cremades, R., Bhowmik, A., \& Hewitt, R. J. (2020). Social tipping dynamics for stabilizing Earth' s climate by 2050. PNAS, 117(5), 2354-2365. https://doi.org/10.1073/pnas.1900577

Paavola, J. (2008). Livelihoods, vulnerability and adaptation to climate change in Morogoro, Tanzania. Environmental Science and Policy, 11, 642-654.

Paavola, J., \& Gouldson, A. (2009a). Interplay of Actors, Scales, Frameworks and Regimes in the Governance of Biodiversity. Environmental Policy and Governance, 158, 148-158. https://doi.org/10.1002/eet.505

Paavola, J., \& Gouldson, A. (2009b). Interplay of Actors, Scales, Frameworks and Regimes in the Governance of Biodiversity. Env. Pol. Gov, 158(19), 148-158. https://doi.org/10.1002/eet.505

Pahl-wostl, C. (2009). A conceptual framework for analysing adaptive capacity and multi-level learning processes in resource governance regimes. Global Environmental Change, 19, 354-365. https://doi.org/10.1016/j.gloenvcha.2009.06.001

Parish, E. S., Herzberger, A. J., Phifer, C. C., \& Dale, V. H. (2018). Transatlantic wood pellet trade demonstrates telecoupled benefits. Ecology and Society, 23(1).

Pelling, M, O'Brien, K., \& Matyas, D. (2015). Adaptation and transformation. Climate Change, 133(2013), 113-127. https://doi.org/10.1007/s10584-014-1303-0

Rademaker, I.F., Jansen, A., Koech, R.K. and Lee v-d.j. (2016). Smallholder dairy value chain interventions: The Kenya Market-Led Dairy Program (KMDP) Status Report. Report CDI16-018. Wageningen: Centre for Development Innovation, Wageningen University Research centre.

Republic of Kenya. Climate change act No. 11 of 2016, Pub. L. No. 11, 1 (2016). Retrieved from www.kenyalaw.org

Rey, A. N. R., Pizarro, J. C., Anderson, C. B., \& Huettmann, F. (2017). Even at the uttermost ends of the Earth : how seabirds telecouple the Beagle Channel with regional and global processes that affect environmental conservation and social-ecological sustainability. Ecology and Society, 22(4). https://doi.org/https://doi.org/10.5751/ES-09771-220431

Rogers, E. (2004). A prospective and retrospective look at the diffusion model. J. of Health Communication, 9, 13-19. https://doi.org/10.1080/10810730490271449

Shimon, O. P., Ogutu, C. A., Mburu, J., \& Nyikal, R. A. (2017). Effect of Global-GAP Policy on Climate Change Perceptions of Smallholder French Beans Farmers in Central and Eastern Regions , Kenya. Climate, 5(27). https://doi.org/10.3390/cli5020027

Shirima E.J.M (1994).Quality and Quantity of maize and sorghum vegetative parts at 
different stages of plant growth as fodder for Livestock.Un published Msc. thesis, Swedish University of Agricultural Sciences, Uppsala, Sweden.

Shu-dong, Z., Mueller, F., Bur, B., Xing-jin, C., \& Ying, H. (2013). Assessing Agricultural Sustainable Development Based on the DPSIR Approach : Case Study in Jiangsu, China. J. of Integrative Agriculture, 12(7), 1292-1299. https://doi.org/10.1016/S2095-3119(13)60434-7

Siegel, P. ., \& Alwang, J. (2005). “Looking at Rural Risk Management Using an Asset-Based approach." Paper prepared for the Commodity Risk Management Group, Agricultural and Rural Development (Managing Agricultural Production Risk Innovations in Developing Countries No. Report No. 32727-GLB). New York.

Sikor, T., He, J., \& Lestrelin, G. (2017). Property Rights Regimes and Natural Resources: A Conceptual Analysis Revisited. World Development. https://doi.org/10.1016/j.worlddev.2016.12.032

Smith, E. K., \& Mayer, A. (2018). A social trap for the climate ? Collective action, trust and climate change risk perception in 35 countries. Global Environmental Change, 49(2018), 140-153. https://doi.org/10.1016/j.gloenvcha.2018.02.014

Solomon, D., Radeny, M., Mungai, C., Recha, J., Schuetz, T., \& Gadeberg, M. (2018). Strategy for supporting agricultural transformation, food and nutrition security under climate change. Adis Ababa. Retrieved from www.ccafs. cgiar.org/regions/east-africa

Steffen, W., Rockström, J., Richardson, K., Lenton, T., Folke, C., \& Liverman, D. (2018). Trajectories of the Earth System in the Anthropocene. PNAS, 115(33), 8252-8259. https://doi.org/10.1073/pnas.1810141115

Steinfeld, H., Wassenaar, T., \& Jutzi, S. (2006). Livestock production systems in developing countries: status, drivers, trends. Rev. Sci. Tech. Off. Int. Epiz, 25(2), 505-516.

Suckall, N., Tompkins, E., \& Stringer, L. (2014). Identifying trade-offs between adaptation , mitigation and development in community responses to climate and socio-economic stresses : Evidence from Zanzibar, Tanzania. Applied Geography, 46, 111-121. https://doi.org/10.1016/j.apgeog.2013.11.005

Svarstad, H., Kjerulf, L., Rothman, D., Siepel, H., \& Watzolde, F. (2008). Discursive biases of the environmental research framework DPSIR. Land Use Policy, 25, 116-125. https://doi.org/10.1016/j.landusepol.2007.03.005

Swart, R., Robinson, J., \& Cohen, S. (2013). Climate change and sustainable development : expanding the options. Climate Policy, 3(sup 1), S19-S40. https://doi.org/https://doi.org/10.1016/j.clipol.2003.10.010

Tessema, Y., Joerin, J., \& Patt, A. (2019). Crop switching as an adaptation strategy to climate change : the case of Semien Shewa Zone of Ethiopia. Ijccm, 11(3), 358-371. https://doi.org/10.1108/IJCCSM-05-2018-0043

Thapa, B., Scott, C., Wester, P., \& Varady, R. (2016). Towards characterizing the adaptive capacity of farmer-managed irrigation systems : learnings from Nepal. Environmental Sustainability, 21, 37-44. https://doi.org/10.1016/j.cosust.2016.10.005

Thorne, P.J., Thornton, P.K., Kruska, R.L., Reynolds, L., Waddington, S. R., Rutherford, A.S. et al., 2002, 'Maize as food, feed and fertiliser in intensifying crop-livestock systems in East and southern Africa: An ex ante impact assessment of technology interventions to improve smallholder welfare', Ilri Impact Assessment Series 11, Nairobi, Kenya: ILRI (International Livestock Research Institute).

Turner, B.L, Kasperson ,P., Matson,J.J., Mcarthy, R.W., Corell, L., Christensen, N., Ekley, J.X., Kaperson, A.,Luers, M.L., Martello, C., Polsky, A. and Schiller, A.(2010): Methods and Models for climate change Analysis in the Arctics. A framework for Vulnerability Analysis in Sustainability Science. Proceedings of the National Academy of Sciences 100:8074-8079 
Tscherning, K., Helming, K., Krippner, B., Sieber, S., \& Gomez, S. (2012). Does research applying the DPSIR framework support decision making ? Land Use Policy, 29(1), 102-110.

https://doi.org/10.1016/j.landusepol.2011.05.009

Tvinnereim, E., \& Mehling, M. (2018). Carbon pricing and deep decarbonisation. Energy Policy, 121, 185-189. https://doi.org/10.1016/j.enpol.2018.06.020

UN. (2015a). conference of Parties (COP 21) Paris Agreement. Paris, France.

UN. (2015b). Transforming the world: the 2030 Agenda for Sustainable Development (No. A/RES/70/1) (Vol. 05445). New York.

UN. (2019). Yearbook of Global Climate Action 2019. Bonn, Germany.

UNEP. (2011). Towards a Green Economy: Pathways to Sustainable Development and Poverty Eradication - A Synthesis for Policy Makers. Towards a Green Economy. Nairobi, Kenya. https://doi.org/10.1063/1.3159605

UNEP (2019). United Nations Environment Programme. Emissions Gaps Report 2019. UNEP, Nairobi, Kenya. https://wedocs.unep.org/bitstream/handle/20.500.11822/30797/EGR2019.pdf. Accessed 17th October, 2020.

UNFCC. (2018). Ad Hoc Working Group on the Paris Agreement: Additional tool under item 3 of the agenda on Nationally Determined Commitments (NDCs). Bangkok.

UNFCC( 1998). Kyoto protocol to the United Nations on Climate. The United Nations Available at http/unfccc.int/resource/docs/2008/tp/0/8.pdf

UNISDR. (2015a). Sendai Framework for Disaster Risk Reduction. Third World Conference on Disaster Risk Reduction, Sendai, Japan, 14-18 March 2015. Sendai, Japan, Japan. https://doi.org/A/CONF.224/CRP.1

UNISDR. (2015b). Sendai Framework for Disaster Risk Reduction 2015-2030. Sendai, Japan. Retrieved from www.unisdr.org

Urwin, K., \& Jordan, A. (2008). Does public policy support or undermine climate change adaptation? Exploring policy interplay across different scales of governance. Global Environmental Change, 18(2008), 180-191. https://doi.org/10.1016/j.gloenvcha.2007.08.002

Volenzo, T. E., Odiyo, J., \& Obiri, J. (2019). Greenhouse gas emissions as sustainability indicators in agricultural sectors ' adaptation to climate change : Policy implications. Journal of Disaster Risk Studies, 11(1), 1-9. https://doi.org/10.4102/ jamba.v11i1.576

Volenzo, T., \& Odiyo, J. O. (2020). Perception of Environmental Spillovers Across Scale in Climate Change Adaptation Planning : The Case of Scale Farmers' Irrigation Strategies, Kenya.Climate, 8(3).

Vuuren, D.-V., Stehfest, E., Gernaat, D. E. H. J., Doelman, J., Berg, M. V.-D., Harmsen, M., ... Ruijven, B.-V. (2017). Energy, land-use and greenhouse gas emissions trajectories under a green growth paradigm. Global Environmental Change, 42, 237-250. https://doi.org/10.1016/j.gloenvcha.2016.05.008

Weitz, N., Strambo, C., Kemp-benedict, E., \& Nilsson, M. (2017). Closing the governance gaps in the water-energy-food nexus : Insights from integrative governance. Global Environmental Change, 45, 165-173. https://doi.org/10.1016/j.gloenvcha.2017.06.006

Wekesa, B., Ayuya, O., \& Lagat, J. (2018). Effect of climate - smart agricultural practices on household food security in smallholder production systems : micro - level evidence from Kenya. Agriculture \& Food Security, 7(80), 1-14. https://doi.org/10.1186/s40066-018-0230-0

Williams, T., Hiernaux, P., \& Fernandez-Rivera, S. (2000). Crop- livestock Systems in SubSaharan Africa: Determinants and Intensification Pathways. In Property Rights, Risk, and Livestock Development in Africa (Vol. 49, pp. 132-151). Washington DC: ILRI/IFRI. https://doi.org/10.1353/arw.2007.0051

World Bank. (2014). Risk and Opportunity: Managing Risk for Development. Washington D.C. 
Retrieved from www.worldbank.org

Xiong, H., Millington, J. . . . \& \& Xu, W. (2018). Trade in the telecoupling framework : evidence from the metals industry. Ecology and Society, 23(1). https://doi.org/https://doi.org/10.5751/ES09864-230111

Xu, E. G. B., Leung, K. M. Y., Morton, B., \& Lee, J. H. W. (2015). An integrated environmental risk assessment and management framework for enhancing the sustainability of marine protected areas: The Cape d' Aguilar Marine Reserve case study in Hong Kong. Science of the Total Environment, 505, 269-281. https://doi.org/10.1016/j.scitotenv.2014.09.088

You, J. (2014). Risk, under-investment in agricultural assets and dynamic asset poverty in rural China. China Economic Review, 29, 27-45. https://doi.org/10.1016/j.chieco.2014.02.002

Zimmerer, K., Lambin, E., \& Vanek, S. (2018). Smallholder telecoupling and potential sustainability. Ecology and Society, 23(1). https://doi.org/https://doi.org/10.5751/ES-09935-230130

Declaration of Interest: The authors declare that they have no financial or personal relationships that may have inappropriately influenced them in writing this article

Author's contribution: Dr. Volenzo Tom Elijah was the originator of research idea and conceptual framework and wrote the manuscript, Prof. John Odiyo advised refined the concept, organisation, editing and revising the manuscript. 